\title{
Water Conserving Irrigation Practices, Plant Growth, Seasonal Crop Coefficients, and Nutrition of Container-Grown Woody Ornamentals
}

\author{
R. Thomas Fernandez ${ }^{1, *(\mathbb{D})}$, Nicholas A. Pershey ${ }^{1}$, Jeffrey A. Andresen ${ }^{2}$ and Bert M. Cregg ${ }^{1}$ \\ 1 Department of Horticulture, Michigan State University, 1066 Bogue St. Rm. A288, \\ East Lansing, MI 48824, USA; persheyn@gmail.com (N.A.P.); cregg@msu.edu (B.M.C.) \\ 2 Department of Geography, Michigan State University, 673 Auditorium Rd. Rm. 236A, East \\ Lansing, MI 48824, USA; andresen@msu.edu \\ * Correspondence: fernan15@msu.edu; Tel.: +01-517-353-0336
}

Received: 3 September 2019; Accepted: 26 September 2019; Published: 3 October 2019

\begin{abstract}
Irrigation practices for container nursery crops often result in over-application and can lead to leaching of nutrients and reduced growth. Our objectives were to: (1) compare growth and foliar nutrient content for plants under daily water use (DWU) based irrigation treatments, (2) determine DWU of 14 woody ornamental taxa, and (3) classify taxa into irrigation functional groups based on crop coefficients $\left(\mathrm{K}_{\mathrm{C}}\right)$. Irrigation was applied daily to 8 taxa in 2009 and 2010 using a control of $19 \mathrm{~mm}$ and three irrigation treatments: (1) replacing $100 \%$ plant DWU (100DWU) each day, (2) alternating $100 \%$ DWU with $75 \%$ DWU in a 2-day cycle (100-75DWU), and (3) a 3-day cycle replacing 100\% DWU the first day and 75\% DWU on the second and third days (100-75-75DWU). In 2009, seasonal average DWU ranged between 8.8 and $17.3 \mathrm{~mm}$ depending on taxa and treatment. Most DWU-based treatments resulted in less water applied than the control, yet plant growth was not reduced, and for one taxon (Hydrangea paniculata 'Limelight') the 100DWU increased plant growth index. Lower foliar $\mathrm{P}$ and $\mathrm{K}$ concentrations were found for several taxa in control versus DWU treatments. In 2010, DWU for the season ranged between 2.1- and 22.0- $\mathrm{mm} \mathrm{d}^{-1}$ depending on taxa and treatment. Growth was lower only for 100-75-75DWU Hydrangea paniculata 'Limelight' compared to other treatments and there were no differences in foliar nutrient content.
\end{abstract}

Keywords: container production; foliar nutrition; nursery production; water management

\section{Introduction}

Container landscape nurseries grow a large number of plants using a correspondingly large amount of inputs per hectare, especially water, to produce an attractive product for consumers. Since container substrates are designed to drain rapidly and containers provide a relatively small reservoir, irrigation is often applied once or more each day. Overhead irrigation is the most common system for container production [1]. Only $13 \%$ to $26 \%$ of the applied overhead irrigation is retained in the container, the remainder lands between containers or is leached out [2]. Additionally, irrigators tend to over-irrigate in order to avoid the negative consequences of drought stress without considering the more subtle negative consequences of over-irrigating [3,4]. In addition to increasing water withdrawals, inefficient irrigation practices also result in greater runoff and nutrient losses through leaching, which can move offsite to contaminate adjacent water resources [5-7]. Moreover, increasing competition between urban and agricultural water use and greater interest in environmental fate of water necessitate improved irrigation practices be developed for agricultural production [8-10].

Improving irrigation management in container production often reduces the amount of water applied, decreases the volume of runoff and reduces nutrient movement in runoff $[6,7,11-13]$. 
Sensor-controlled irrigation systems can reduce irrigation applications between $30 \%$ to $75 \%$, depending on species, with little to no effect on plant growth $[3,6,7,13,14]$. Sensor-based irrigation can also reduce total quantities of nitrates and phosphates in effluent [6,7]. Furthermore, when used to schedule irrigation, soil moisture sensors reduce crop losses due to disease and increase profit for ornamental plant producers [4].

When using ET-based irrigation scheduling, a reference ET $\left(\mathrm{ET}_{0}\right)$ and the crop coefficient $\left(\mathrm{K}_{\mathrm{C}}\right)$ must be known [15]. $\mathrm{ET}_{0}$ is often available from local agricultural weather reports. While $\mathrm{K}_{\mathrm{C}}$ values have been determined for a wide variety of field-grown crops, $K_{C}$ values have been estimated for only a few dozen out of the thousands of woody ornamental taxa grown today $[6,13,16,17]$. The determination of $\mathrm{K}_{\mathrm{C}}$ for more taxa of container-grown is necessary for ET-based models to be useful in irrigation scheduling. To reduce the need to determine $\mathrm{K}_{\mathrm{C}}$ for every container taxa grown today, Yeager [18] suggests using indicator species to group plants having similar water needs into the same irrigation blocks. However, there is little quantitative data regarding container plant water use to allow selection of indicator plants or to group plants by water needs.

The objectives of this project were to compare the effects of three irrigation treatments based on plant daily water use (DWU) to a control daily irrigation rate of $19 \mathrm{~mm} \mathrm{~d}^{-1}$ for woody ornamental shrubs produced in containers. Plant growth index (GI) and dry weight, DWU, $\mathrm{K}_{\mathrm{C}}$, water use efficiency (WUE), substrate leachate electrical conductivity (EC) and $\mathrm{pH}$, and foliar nutrient concentrations were determined to compare the 3 DWU-based irrigation treatments with the control.

\section{Materials and Methods}

\subsection{Site}

The Michigan State University Horticulture Teaching and Research Center, Holt, Mich., USA is located at latitude $42.67^{\circ} \mathrm{N}$, longitude $-84.48^{\circ} \mathrm{W}$, and elevation of $264 \mathrm{~m}$. Plants were grown on a site representative of a typical production nursery. Containers were placed on a level surface of limestone gravel underlain at a $15 \mathrm{~cm}$ depth with woven polypropylene permeable landscape fabric to reduce weed emergence and subsidence of the gravel. There were 12 irrigation zones with dimensions $4.9 \mathrm{~m}$ $\mathrm{N}$ to $\mathrm{S} \times 7.3 \mathrm{~m}$ E to $\mathrm{W}$ and spaced $0.3 \mathrm{~m}$ apart. An on-site Michigan Enviro-weather station [19] was used to monitor environmental conditions including calculation of $\mathrm{ET}_{0}$ with the modified Penman equation [15].

\subsection{Irrigation System}

Irrigation was activated in each production bed by $1.9 \mathrm{~cm}$ diameter $24 \mathrm{~V}$ alternating current solenoid valves. Irrigation nozzles (Pro-Spray ${ }^{\circledR}$, Hunter Industries Incorporated; San Marcos, CA, USA) were mounted on $1.3 \mathrm{~cm}$ diameter by $0.66 \mathrm{~m}$ high risers. The nozzles were spaced $2.44 \mathrm{~m}$ apart along the perimeter of each irrigation zone with all water directed inward. Four $90^{\circ}$ nozzles were positioned on the corners of the irrigation zone, two $180^{\circ}$ nozzles were positioned between the corner nozzles on each $\mathrm{E}-\mathrm{W}$ perimeter, one $180^{\circ}$ nozzle was placed on both the $\mathrm{N}$ and $\mathrm{S}$ edges of irrigation zone, and two $360^{\circ}$ nozzles were positioned along the centerline of the irrigation zone. Each nozzle had a $2.44 \mathrm{~m}$ radius of throw to provide $100 \%$ nozzle-to-nozzle overlap.

Irrigation system distribution uniformity (DU) and application rate in each treatment replicate were determined in 2009 and 2010 using 16 rain gauges randomly interspersed throughout the irrigation zone and allowed to collect water for $20 \mathrm{~min}$ as described in Dudek and Fernandez [20]. The average application rate and DU was $47.3 \mathrm{~mm} \cdot \mathrm{hr}^{-1}$ and $74.8 \%$ in 2009 and $46.4 \mathrm{~mm} \cdot \mathrm{hr}^{-1}$ and $76.8 \%$ in 2010.

\subsection{Plant Material}

Rooted cuttings of Aronia arbutifolia Persh. 'Brilliantissima', Cornus sericea L. 'Farrow', Hydrangea paniculata Sieb. 'Limelight', Itea virginica L. 'Morton', Physocarpus opulifolius Maxim. 'Seward', Spiraea media F. Schmidt 'Darsnorm', Thuja plicata Donn. 'Grovepli', and Weigela florida A. DC. 'Alexandra' 
were obtained from a commercial nursery in $5.7 \times 5.7 \mathrm{~cm}$ plug containers on 1 August 2008 . They were planted in $10.2 \mathrm{~L}$ containers with an 85 pine bark: 15 peat moss (vol:vol) substrate between 2 September to 9 September 2008 for use in the 2009 study. Cuttings from the same nursery of Hydrangea arborescens L. 'Abetwo', Hydrangea paniculata 'Limelight', Rhus aromatica Aiton 'Gro-Low', Spiraea fritschiana C.K. Schneid. 'Wilma', Syringa meyeri C.K. Schneid. 'Palibin', Syringa xhyacinthiflora Rehd. 'Evangeline', Viburnum dentatum L. 'Ralph Senior', and Weigela florida 'Alexandra' were potted as described above between 15 September to 18 September 2009 for use in the 2010 study. All cultural practices in both years except irrigation were identical for all treatments. On 9 June 2009 and 22 June 2010, each container was top-dressed with $54 \mathrm{~g}$ of $19 \mathrm{~N}-2.6 \mathrm{P}-10 \mathrm{~K}$ controlled release fertilizer with micronutrients (5-6-month release at $26.7^{\circ} \mathrm{C}$ or $21.1^{\circ} \mathrm{C}$, Polyon ${ }^{\circledR}$ Reactive Layers Coating, Harrell's Inc., Lakeland, FL). Weeds were removed by hand pulling as necessary. Plants were overwintered each winter in a minimally-heated $\left(-2.2^{\circ} \mathrm{C}\right.$ minimum temperature) quonset house covered with 4 mil overwintering film permitting $30 \%$ light transmission. In May of each year, the film was removed and plants were irrigated to container capacity as needed until beginning the treatments.

\subsection{Experimental Design}

A control and three irrigation treatments were replicated three times and assigned to the 12 irrigation zones in a completely randomized design. The control was application of $19 \mathrm{~mm} \cdot \mathrm{d}^{-1}$, and the treatments were (1) irrigation applied to replace $100 \%$ daily water use (100DWU) each day, (2) applications alternating 100\% DWU with 75\% DWU in a 2-day cycle (100-75DWU), and (3) a 3-day application cycle replacing 100\% DWU on the first day and 75\% DWU on the second and third days (100-75-75DWU). Each treatment replicate contained six subreplicates of each of the eight shrub species for a total of 48 experimental plants in each treatment replicate. Experimental plants were randomized in six rows of eight at the center of the irrigation zone and inset at least $1.2 \mathrm{~m}$ from the edge with guard plants surrounding the perimeter to reduce edge effects. Guard plants consisted of several species having similar growth rates to the experimental plants and were arranged in the same sequence in each treatment replicate.

\subsection{Daily Water Use and Irrigation Scheduling, 2009}

Substrate volumetric water content $(\theta)$ was measured in 2009 for every plant using time domain reflectometry (TDR) soil moisture sensors (ThetaProbe Type mL2x, Delta-T Devices Ltd., Cambridge, UK) connected to a handheld reader (ThetaMeter Hand-Held Readout Unit Type HH1, Delta-T Devices Ltd., Cambridge, UK). For each container, the soil moisture sensor was inserted vertically into the substrate halfway between the center and the outer wall of the container to a depth of $6 \mathrm{~cm}$ in three locations $120^{\circ}$ apart. Volumetric water contents were calibrated for organic substrate using an equation developed by Warsaw et al. [13] for the same substrate. On 11 June 2009, at initiation of the study, irrigation was applied until the substrate for all plants exceeded container capacity. Gravimetric water was allowed to drain for $30 \mathrm{~min}$.

Daily water use for each plant was calculated as:

DWU $=\left(\theta_{\mathrm{i}}-\theta_{\mathrm{f}}\right) \times$ container substrate volume

where:

DWU = daily water use in $\mathrm{L}$

$\theta_{\mathrm{i}}=$ initial volumetric water content $(\%)$ after gravitational water drained

$\theta_{\mathrm{f}}=$ final volumetric water content $(\%)$ after $24 \mathrm{~h}$

container substrate volume $=9.7 \mathrm{~L}$

Control and DWU-based treatments were programmed into a time-based controller (Rain Bird ESP-12LX Plus, Rain Bird Corporation, Azusa, CA, USA) for the period until the next measurement of DWU. New DWU were obtained approximately every $21 \mathrm{~d}$. Overhead irrigation was applied daily from 11 June 2009 (Day 1) to 14 October 2009 (Day 126) beginning at 0700 HR based on the DWU of the 
lowest water user(s). Any taxa requiring more than $50 \mathrm{~mL}(0.89 \mathrm{~mm})$ over the base irrigation level received the balance by hand watering.

\subsection{Daily Water Use and Irrigation Scheduling, 2010}

In 2010, irrigation treatments were similar except that time capacitance soil moisture sensors (model 10HS, Decagon Devices, Inc., Pullman, WA) replaced the TDR sensor to provide continuous $\theta$ sampling and real-time irrigation control. A total of 96 sensors, one per species in each replicate, were connected in single-ended configuration to a datalogger system (AM16/32B multiplexer and CR3000 datalogger, Campbell Scientific, Inc., Logan, UT, USA). The datalogger recorded $\theta$ for each sensor at $15 \mathrm{~min}$ intervals from 7 June to 31 October 2010. A relay controller (SDM-CD16AC, Campbell Scientific, Inc., Logan, UT, USA) was connected to the datalogger to control the irrigation solenoid valves for each treatment replicate.

On 20 June 2010, each of the 96 sensors was individually calibrated in situ to the substrate moisture content. Irrigation was applied to bring the substrate to container capacity, and each container was weighed after drainage ceased using a PM 30 electric balance (Mettler-Toledo, Inc. Columbus, $\mathrm{OH}$, USA). Five subsequent weights were taken during a 2-d dry-down period and recorded with coinciding sensor output. These data were plotted using Microsoft Excel (2007) and the trend line feature was used to obtain a single best-fit quadratic equation. Calibrations were verified using the PROC REG function in SAS (SAS Institute; Cary, NC, USA) before inclusion in the datalogger program. The calibration equations were then incorporated in the datalogger programming using Version 2.7.0.16 of CRBasic Editor (Campbell Scientific, Inc., 2006, Logan, UT, USA). Daily Water Use was calculated based on the daily change in $\theta$ and container substrate volume as in the previous year.

Irrigation run time was then calculated for each taxon in the irrigation zone by:

$$
\text { Run Time }=\text { DWU/AR }
$$

where $\mathrm{AR}$ is the irrigation application rate as determined above. The program used the highest run time from the 8 plant taxa multiplied by the appropriate treatment fraction $(100 \%$ or $75 \%$, depending on treatment cycle) to apply irrigation for the proper duration.

\subsection{Plant Response}

Crop coefficients $\left(\mathrm{K}_{\mathrm{C}}\right)$ were determined for each taxon receiving 100DWU (well-watered and no limitations on crop growth or evapotranspiration) using the formula $\mathrm{K}_{\mathrm{C}}=\mathrm{ET}_{\mathrm{A}} / \mathrm{ET}_{0}$ [15], where $\mathrm{ET}_{\mathrm{A}}$ is actual crop evapotranspiration (measured as DWU) and $\mathrm{ET}_{0}$ is reference evapotranspiration obtained from the on-site weather station. An adjusted $\mathrm{K}_{\mathrm{C}}\left(\mathrm{K}_{\mathrm{Cadj}}\right)$ was determined using the same equation for the plants under potentially growth and/or ET limiting conditions [15], e.g., the control and deficit irrigation treatments. Plants were classified as low $\left(K_{C}<2\right)$, moderate $\left(2 \leq K_{C}<3\right)$, or high $\left(K_{C} \geq 3\right)$ water users as described by Warsaw et al. [13].

Monthly growth index (GI) was calculated as the average of plant height $(\mathrm{H})$ from the container rim to the highest point of the plant and plant widths along the north-south $\left(\mathrm{W}_{\mathrm{NS}}\right)$ and the east-west axis $\left(\mathrm{W}_{\mathrm{EW}}\right)$ axis [GI $=\left(\mathrm{H}+\mathrm{W}_{\mathrm{NS}}+\mathrm{W}_{\mathrm{EW}}\right) / 3$ ]. Prior to the first measurement, all taxa were pruned to a uniform size. Plant shoot dry weight for Rhus aromatica 'Gro-Low', Viburnum dentatum 'Ralph Senior', and Weigela florida 'Alexandra' was measured at the end of the experiment in 2010 using three plants from each treatment replicate. The stem was cut at the substrate surface and the entire top was bagged, oven (Grieve Corp. model SC400, Round Lake, IL, USA) dried at $80^{\circ} \mathrm{C}$ until no change in dry weight was detected, and weighed.

The pour-through extraction method [21] was used to determine electrical conductivity (EC) and $\mathrm{pH}$ using a portable EC meter and a portable $\mathrm{pH}$ meter (Horiba Cardy Twin EC and Horiba Cardy Twin pH, Spectrum Technologies, Inc., Plainfield, IL, USA). Leachate was collected 30 to $60 \mathrm{~min}$ 
after irrigation for each taxon using the same plants each time 3 times throughout 2009 and 6 times throughout 2010.

Foliar samples for nutrient analysis were collected mid-season and late-season from five taxa in 2009 and six taxa in 2010. Sixty recently fully expanded leaves were collected for each treatment replicate for each taxon (approximately 10 leaves per subreplicate). Percent (dry weight) N, P, K, Ca, Mg, Na, S, and concentration of $\mathrm{Fe}, \mathrm{Zn}, \mathrm{Mn}, \mathrm{Cu}, \mathrm{B}$, and $\mathrm{Al}$ were determined. The Dumas combustion procedure (AOAC 968.06) [22] was used to determine foliar N. Other minerals were dissolved from organic material using open vessel microwave digestion (SW846-3050B) with mineral analysis determined using inductively coupled argon plasma (ICAP analysis (AOAC 985.01) [22].

\subsection{Statistical Analysis}

Analysis of variance was conducted for irrigation volume, DWU, $\mathrm{K}_{\mathrm{C}}, \mathrm{GI}$, dry weight, substrate $\mathrm{EC}$ and $\mathrm{pH}$, and foliar nutrient content using the PROC GLM procedure of SAS (SAS Version 9.1; SAS Institute, Cary, NC) and data normality were checked using the PROC UNIVARIATE procedure. DWU data showed several outliers due to a variety of factors ranging from sensors becoming dislodged in the substrate to rodent damage of sensor cables. Consequently, any DWU values in excess of $3000 \mathrm{~mL}$ were excluded from the analyses for DWU, $K_{C}$, and WUE. When significant $(\alpha \leq 0.05)$ differences among treatments or taxa were indicated, Tukey's Honestly Significant test was used to separate means. On 31 August 2010 (day 70) in the last replicate to run each day (a 100-75-75DWU replicate), a fault caused the farm irrigation pump to shut off prematurely for 4 days resulting in no irrigation for the replicate. Therefore, data from that replicate was excluded from analysis of DWU and $\mathrm{K}_{\mathrm{C}}$ throughout the entire season and GI, EC, $\mathrm{pH}$, and foliar nutrient concentration from day 70 onward.

\section{Results}

\subsection{Irrigation Volume, Daily Water Use, and Plant Growth}

Cumulative and average daily $\mathrm{ET}_{0}$ for the 2009 treatment period (126 days) equaled $414 \mathrm{~mm}$ and $3.3 \mathrm{~mm}$ and in 2010 (131 days) were $431 \mathrm{~mm}$ and $3.3 \mathrm{~mm}$. During the treatment period, total irrigation applied to the control was $2483 \mathrm{~mm}\left(134.1{\left.\mathrm{~L} \cdot \text { container }^{-1}\right)}\right.$ in 2009 and $2594 \mathrm{~mm}\left(140.1{\mathrm{~L} \cdot \text { container }^{-1}}^{-1}\right.$ ) in 2010 (Table 1). A total of $310 \mathrm{~mm}$ and $233 \mathrm{~mm}$ of rainfall occurred during the 2009 and 2010 treatment periods (Figure 1). Irrigation was not applied on 5 days in 2009 and 3 days in 2010 when rainfall events exceeded $19 \mathrm{~mm}$ (Figure 1). Temperature and solar flux were highest in July and August before declining from September until the end of data collection in each year (Figure 2).

H. paniculata 'Limelight' required the most irrigation and I. virginica 'Morton' the least in 2009. Compared to their respective controls, irrigation was reduced for $H$. paniculata 'Limelight' by 7\%, 19\%, and $23 \%$ for $100 \mathrm{DWU}, 100-75 \mathrm{DWU}$, and 100-75-75DWU, respectively, and by $48 \%, 55 \%$, and $57 \%$ for $I$. virginica 'Morton' for 100DWU, 100-75DWU, and 100-75-75DWU, respectively, with reductions for other taxa in between (Table 1). In 2010, irrigation was based on the highest DWU among taxa within each treatment, therefore, there are no differences in irrigation due to taxa, only treatment (Table 1). Compared to the control, total irrigation applications in 2010 were $19 \%$ and $50 \%$ greater for $100 \mathrm{DWU}$ and 100-75DWU while 100-75-75DWU received 18\% less.

Since the 75DWU irrigation rates in 2009 were based on the 100DWU irrigation rate it is possible to have different measured seasonal DWU (Table 2) than total amount of irrigation applied (Table 1) for 100-75DWU and 100-75-75DWU. Average DWU was highest in 2009 for 100DWU H. paniculata 'Limelight' and lowest for 100DWU A. arbutifolia 'Brilliantissima' (Table 2). In 2009, only C. sericea 'Farrow' and I. virginica 'Morton' had differences within species due to treatment, where 100DWU was lower than control. In 2010, the highest DWU occurred for 6 of the 8 taxa in 100DWU or 100-75DWU treatments. Both Hydrangea species typically had the highest DWU among taxa within a treatment. The lowest water use taxa included S. meyeri 'Palibin' and V. dentatum 'Ralph Senior' in the control and 100-75 DWU, and S. xhyacinthiflora 'Evangeline' in 100DWU, 100-75DWU and 100-75-75DWU. 
Table 1. Total irrigation application (L·container ${ }^{-1}$ ) to 4 irrigation treatments from 11 June (Day 1 ) to 14 October 2009 (Day 126) and 23 June (Day 1) to 31 October 2010 (Day 131). Control = $19 \mathrm{~mm} \cdot$ application $^{-1}\left(1.07 \mathrm{~L} \cdot\right.$ container $^{-1} \cdot$ day $\left.^{-1}\right) ; 100 \mathrm{DWU}=100 \%$ daily water use (DWU) replacement each day; 100-75DWU = 2 day cycle alternating 100\% DWU and 75\% DWU; and 100-75-75DWU = 3 day cycle $100 \%$ DWU replacement the first day then 2 days $75 \%$ DWU replacement. Overhead irrigation scheduling based on 2009) lowest DWU of the 8 taxa during each measurement period with remaining water requirement supplied by hand each day as necessary; 2010) highest DWU of the 8 taxa in each treatment replicate each day.

\begin{tabular}{ccccc}
\hline Taxa & Control & 100DWU & 100-75DWU & 100-75-75DWU \\
\hline \multicolumn{4}{c}{2009} \\
\hline Aronia arbutifolia 'Brilliantissima' & $134.1 \mathrm{~A}$ z & $78.2 \mathrm{~B}$ & $68.6 \mathrm{C}$ & $65.4 \mathrm{C}$ \\
Cornus sericea 'Farrow' & $134.1 \mathrm{~A}$ & $100.5 \mathrm{~B}$ & $88.3 \mathrm{C}$ & $84.3 \mathrm{C}$ \\
Hydrangea paniculata 'Limelight' & $134.1 \mathrm{~A}$ & $124.7 \mathrm{~B}$ & $108.8 \mathrm{C}$ & $103.3 \mathrm{C}$ \\
Itea virginica 'Morton' & $134.1 \mathrm{~A}$ & $69.1 \mathrm{~B}$ & $60.5 \mathrm{C}$ & $57.6 \mathrm{C}$ \\
Physocarpus opulifolius 'Seward' & $134.1 \mathrm{~A}$ & $100.7 \mathrm{~B}$ & $88.1 \mathrm{C}$ & $84.1 \mathrm{C}$ \\
Spiraea media 'Darsnorm' & $134.1 \mathrm{~A}$ & $78.8 \mathrm{~B}$ & $69.3 \mathrm{C}$ & $66.1 \mathrm{C}$ \\
Thuja plicata 'Grovepli' & $134.1 \mathrm{~A}$ & $76.9 \mathrm{~B}$ & $67.3 \mathrm{C}$ & $64.1 \mathrm{C}$ \\
Weigela florida 'Alexandra' & $134.1 \mathrm{~A}$ & $113.5 \mathrm{~B}$ & $99.3 \mathrm{~B}$ & $94.8 \mathrm{BC}$ \\
\hline & \multicolumn{3}{c}{2010} & \\
\hline All taxa & $140.1 \mathrm{C}$ & $167.3 \mathrm{~B}$ & $209.8 \mathrm{~A}$ & $115 \mathrm{D}$
\end{tabular}

$\mathrm{z}$ Means followed by the same uppercase letters within rows are not different. Means separation performed with Tukey's Test $(\alpha=0.05), n=3$.

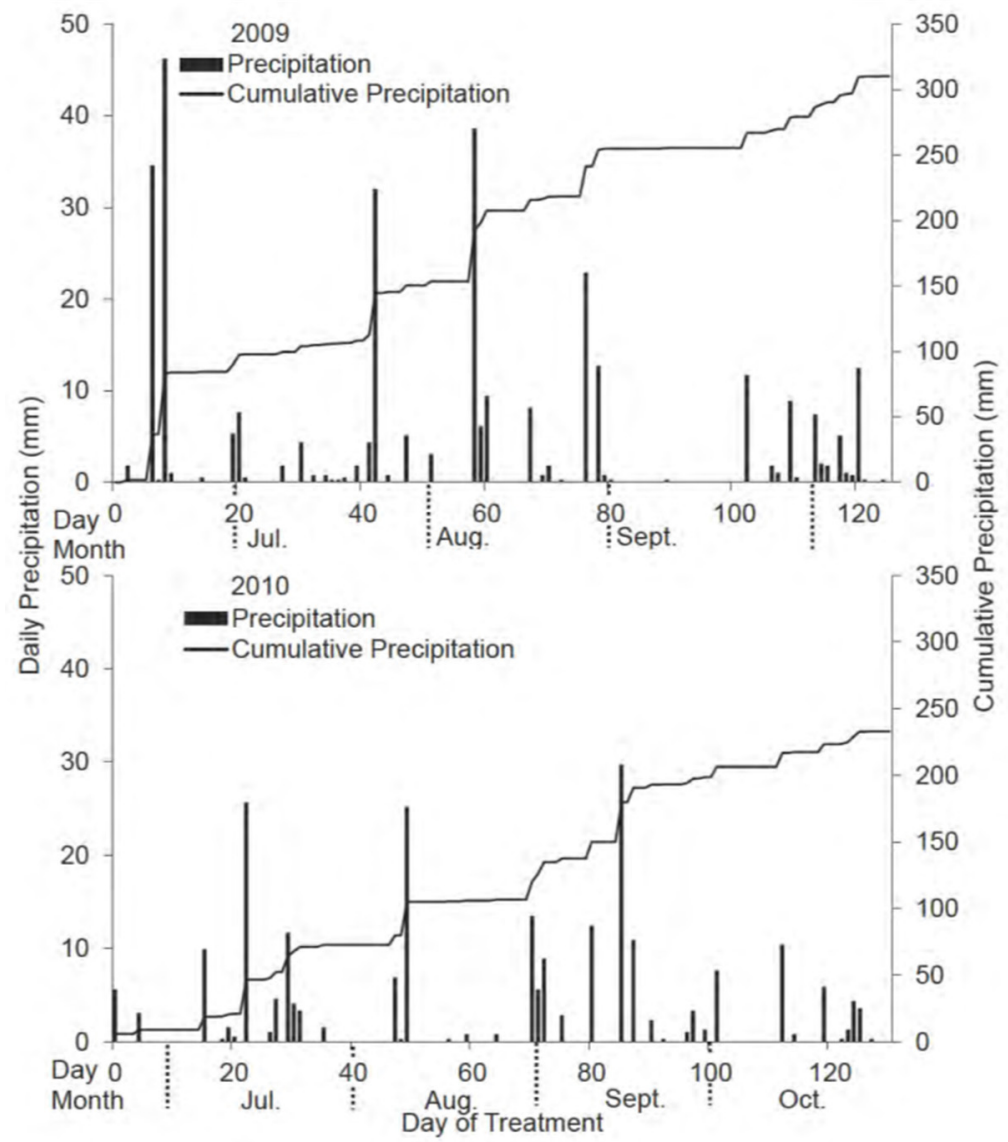

Figure 1. Daily (bars) and cumulative (line) precipitation from 11 June to 14 October (Day 126) 2009 and 23 June to 31 October 2010 (Day 131). 


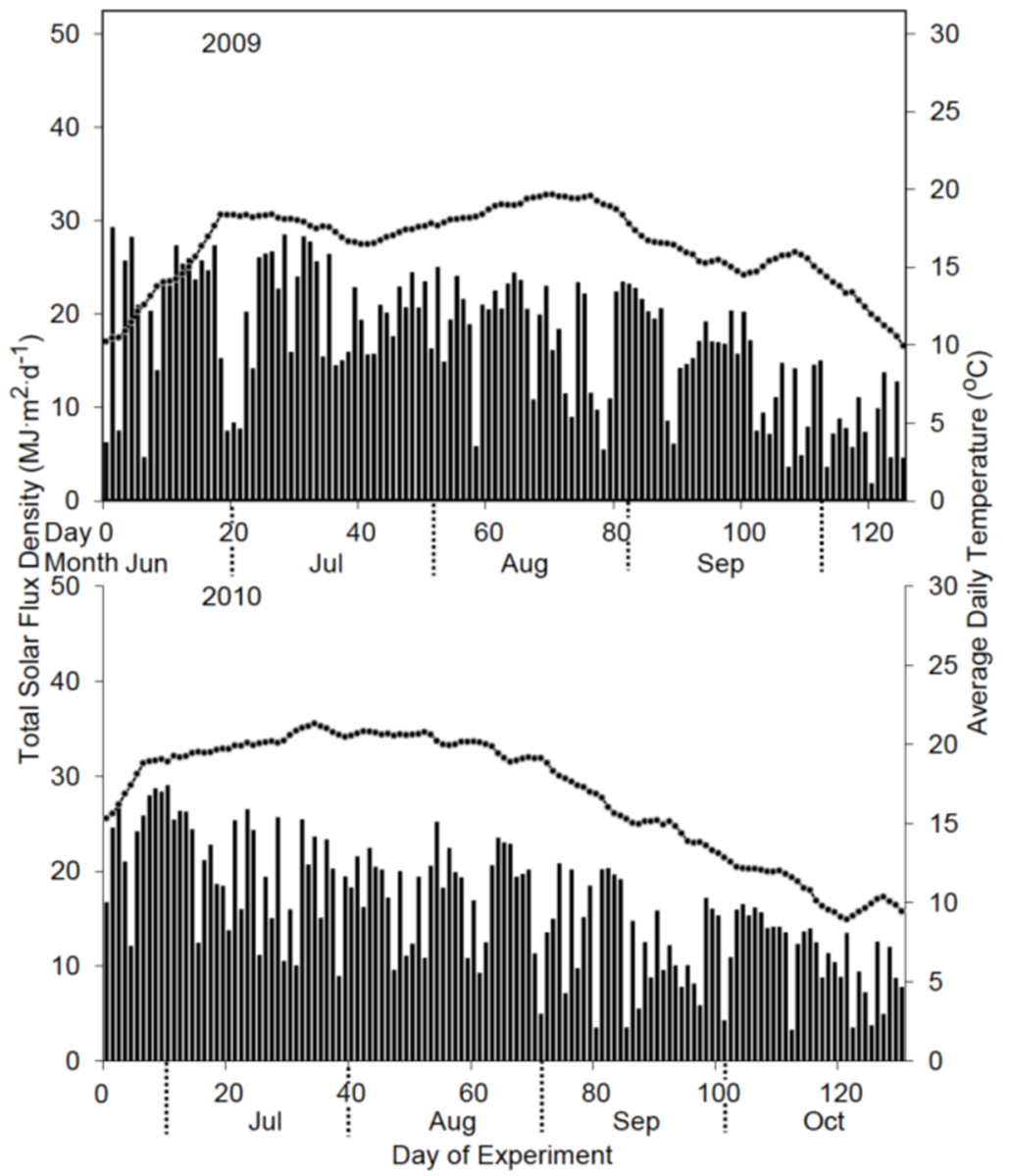

Figure 2. Daily total solar flux density (bars) and daily average temperature (line) from 11 June (Day 1) to 14 October (Day 126) 2009 and 23 June (Day 1) to 31 October 2010 (Day 131).

Table 2. Season average daily irrigation application $\left(\mathrm{mm} \cdot\right.$ container $\left.^{-1}\right)$ and average daily water use $\left(\mathrm{mm} \cdot\right.$ container $^{-1}$ ) of eight shrubs grown in $10.2 \mathrm{~L}$ containers under four irrigation treatments administered 11 June (Day 1) to 14 October 2009 (Day 126) and 23 June (Day 1) to 31 October 2010 (Day 131). Control $=19 \mathrm{~mm} \cdot$ application $^{-1}\left(1.02 \mathrm{~L} \cdot\right.$ day $\left.^{-1}\right) ; 100 \mathrm{DWU}=100 \%$ daily water use (DWU) replacement each day; $100-75 \mathrm{DWU}=2$-day cycle alternating $100 \%$ DWU and 75\% DWU; and 100-75-75DWU = 3-day cycle with 100\% DWU replacement the first day then 2 days 75\% DWU replacement. Overhead irrigation scheduling based on 2009) lowest DWU of the 8 taxa during each measurement period with remaining water requirement supplied by hand each day in DWU treatments as necessary; 2010) highest DWU of the 8 taxa in each treatment replicate each day.

\begin{tabular}{|c|c|c|c|c|}
\hline 2009 & Control & 100DWU & 100-75DWU & 100-75-75DWU \\
\hline Average water application $\left(\mathrm{mm} \cdot \mathrm{d}^{-1}\right)$ & $19.0 \mathrm{~A}^{\mathrm{z}}$ & $9.8 \mathrm{~B}$ & $8.6 \mathrm{C}$ & $8.2 \mathrm{C}$ \\
\hline Taxa & \multicolumn{4}{|c|}{ Daily Water Use } \\
\hline Aronia arbutifolia 'Brilliantissima' & $10.7 \mathrm{Aa}$ & $8.8 \mathrm{Ac}$ & $9.4 \mathrm{Ac}$ & $10.5 \mathrm{Ac}$ \\
\hline Cornus sericea 'Farrow' & $14.9 \mathrm{Aa}$ & $10.0 \mathrm{Bbc}$ & 13.2 ABab & 13.4 ABbc \\
\hline Hydrangea paniculata 'Limelight' & $14.0 \mathrm{Aa}$ & $17.3 \mathrm{Aa}$ & 15.9 Аа & $17.1 \mathrm{Aa}$ \\
\hline Itea virginica 'Morton' & $12.9 \mathrm{Aa}$ & $9.6 \mathrm{Bbc}$ & $10.6 \mathrm{ABbc}$ & $10.6 \mathrm{ABc}$ \\
\hline Physocarpus opulifolius 'Seward' & $13.1 \mathrm{Aa}$ & $13.2 \mathrm{Ab}$ & 13.0 Aab & 14.6 Aab \\
\hline Spiraea media 'Darsnorm' & $10.7 \mathrm{Aa}$ & $9.7 \mathrm{Abc}$ & $12.4 \mathrm{Abc}$ & $11.5 \mathrm{Abc}$ \\
\hline Thuja plicata 'Grovepli' & $11.0 \mathrm{Aa}$ & $9.0 \mathrm{Ac}$ & $9.0 \mathrm{Ac}$ & $11.7 \mathrm{Abc}$ \\
\hline Weigela florida 'Alexandra' & $14.9 \mathrm{Aa}$ & $11.9 \mathrm{Abc}$ & $13.5 \mathrm{Cab}$ & 13.9 Aabc \\
\hline \multicolumn{5}{|l|}{2010} \\
\hline Average water application $\left(\mathrm{mm} \cdot \mathrm{d}^{-1}\right)$ & $19.1 \mathrm{C}$ & $22.8 \mathrm{~B}$ & $28.6 \mathrm{~A}$ & $15.4 \mathrm{D}$ \\
\hline Taxa & \multicolumn{4}{|c|}{ Daily Water Use } \\
\hline
\end{tabular}


Table 2. Cont.

\begin{tabular}{|c|c|c|c|c|}
\hline Hydrangea arborescens 'Abetwo' & 12.1 Bab & $8.9 \mathrm{Cbc}$ & $20.5 \mathrm{Aa}$ & $5.0 \mathrm{Db}$ \\
\hline Hydrangea paniculata 'Limelight' & $14.1 \mathrm{Ca}$ & $17.4 \mathrm{Ba}$ & $22.0 \mathrm{Aa}$ & 8.8 Da \\
\hline Rhus aromatica 'Gro-Low' & $\begin{array}{c}12.4 \\
\mathrm{ABab}\end{array}$ & $10.9 \mathrm{Bb}$ & $13.7 \mathrm{Ab}$ & $5.6 \mathrm{Cb}$ \\
\hline Spiraea fritschiana 'Wilma' & $8.1 \mathrm{Bc}$ & $10.6 \mathrm{Ab}$ & $7.4 \mathrm{Bc}$ & $4.9 \mathrm{Cb}$ \\
\hline Syringa meyeri ‘Palibin' & $3.6 \mathrm{BCd}$ & 7.0 Acd & 4.8 Bd & $2.7 \mathrm{Ccd}$ \\
\hline Syringa xhyacinthiflora 'Evangeline' & $10.3 \mathrm{Abc}$ & $2.2 \mathrm{Cf}$ & $3.4 \mathrm{Bd}$ & $2.1 \mathrm{Cd}$ \\
\hline Viburnum dentatum 'Ralph Senior' & $4.4 \mathrm{Bd}$ & 6.6 Ade & $4.1 \mathrm{Bd}$ & $4.5 \mathrm{Bbc}$ \\
\hline Weigela florida 'Alexandra' & $9.4 \mathrm{Ac}$ & $4.8 \mathrm{Be}$ & $5.3 \mathrm{Bd}$ & $8.4 \mathrm{Aa}$ \\
\hline
\end{tabular}

${ }^{\mathrm{z}}$ Means followed by the same uppercase letters within rows or followed by the same lowercase letters within columns are not different by Tukey's Test $(\alpha=0.05)$. Average daily irrigation application: 2009) $n=126,2010$ ) $n=393$. Average DWU: 2009) $n=108,2010) n=393$.

For both years, DWU generally increased from June to mid-August, declined in September, and plateaued late September through October (Figures 3 and 4). In 2009 (Figure 3), DWU peaked on day 52 for all taxa and DWU exceeded the control irrigation rate for C. sericea 'Farrow' (20 mm), H. paniculata 'Limelight' (28 mm), P. opulifolius 'Seward' ( $25 \mathrm{~mm})$, and W. florida 'Alexandra' (20 mm). Therefore, from day 52 until the next measurement of DWU (day 81), these taxa were receiving more irrigation than the control. No other taxa had DWU at or above the control on any other sampling day except $W$. florida 'Alexandra' on day 76. In 2010 (Figure 4), DWU peaked on Day 55 for H. arborescens 'Abetwo' (36 mm), H. paniculata 'Limelight' (43 mm), R. aromatica 'Gro-low' (32 mm), and W. florida 'Alexandra' $(23 \mathrm{~mm})$. For Hydrangea arborescens 'Abetwo', H. paniculata 'Limelight', and R. aromatica 'Gro-low', DWU peaked above the control irrigation rate for 19,52, and 27 days, respectively. In contrast, many days preceding or following peak days had DWU below the control.
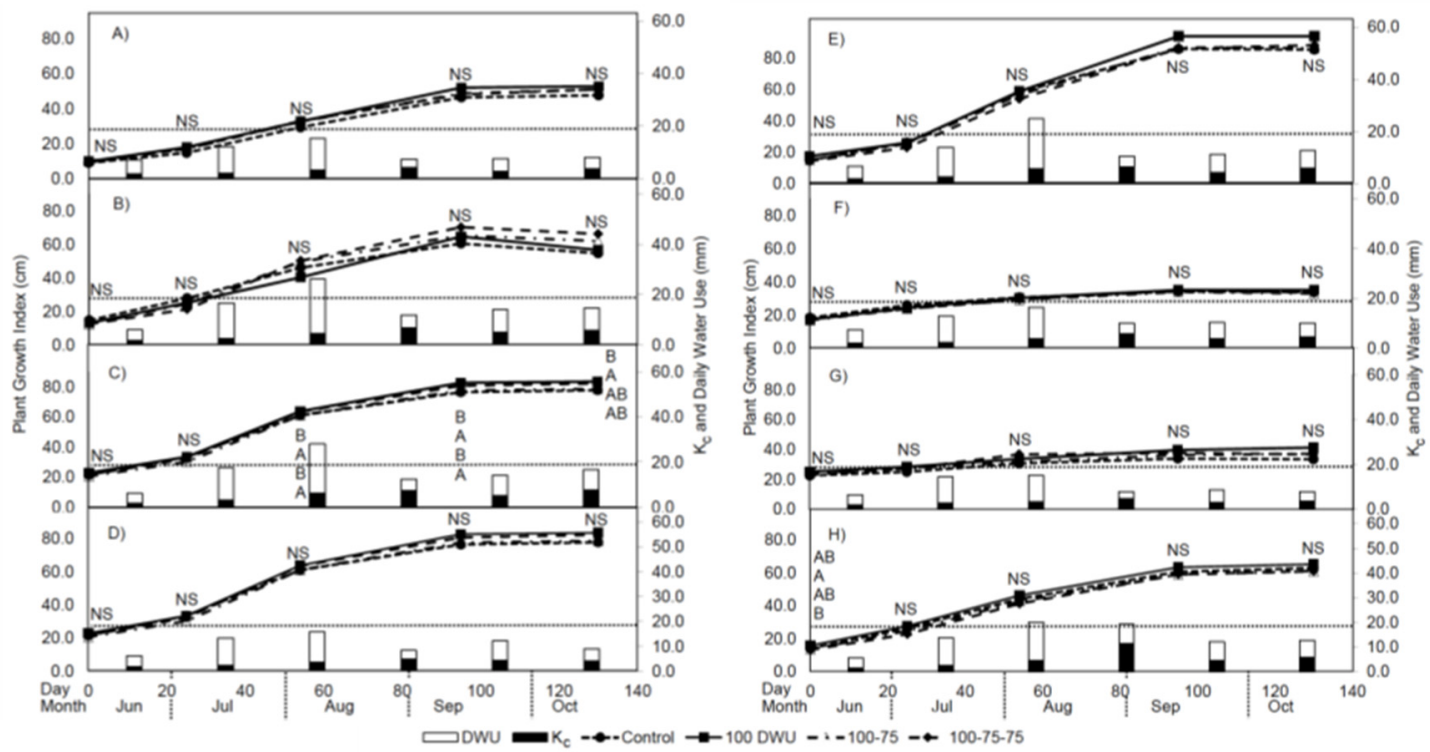

Figure 3. Plant Growth Index (GI), Daily Crop Coefficient $\left(\mathrm{K}_{\mathrm{C}}\right)$, and Daily Water Use (DWU) from 10 June (Day 0) to 14 October 2009 (Day 126) for (A) Aronia arbutifolia 'Brilliantissima', (B) Cornus sericea 'Farrow', (C) Hydrangea paniculata 'Limelight', (D) Itea virginica 'Morton', (E) Physocarpus opulifolius 'Seward', (F) Spiraea media 'Darsnorm', (G) Thuja plicata 'Grovepli', and (H) Weigela florida 'Alexandra' grown in 10.2 L containers. Left y-axis indicates PGI (lines). Control $=19 \mathrm{~mm} \cdot$ application $^{-1} ; 100 \mathrm{DWU}=$ $100 \%$ daily water use (DWU) replacement each day; 100-75DWU = 2-day cycle alternating 100\% DWU and 75\% DWU; and 100-75-75DWU $=3$ day cycle with 100\% DWU replacement the first day then 2 days $75 \%$ DWU replacement. Each day was analyzed separately (Tukey's test, $\alpha=0.05, n=18$ ). Means followed by the same letters are not different. NS = not significant. Right $y$-axis indicates DWU where the entire bars represent DWU $(\mathrm{mm})$ averaged from all treatments $(n=72)$; shaded portions of bars 
represent daily $\mathrm{K}_{\mathrm{C}}$ (DWU: $\mathrm{ET}_{0}, n=72$ ). Overhead irrigation scheduling based on lowest DWU of the 8 taxa during each measurement period; remaining water requirement supplied by hand each day as necessary. ${ }^{y}$ Different letters denote significant differences between treatments in order from top to bottom: Control, 100DWU, 100-75DWU, 100-75-75DWU with A associated with the greatest mean value and subsequent letters associated with lower mean values.
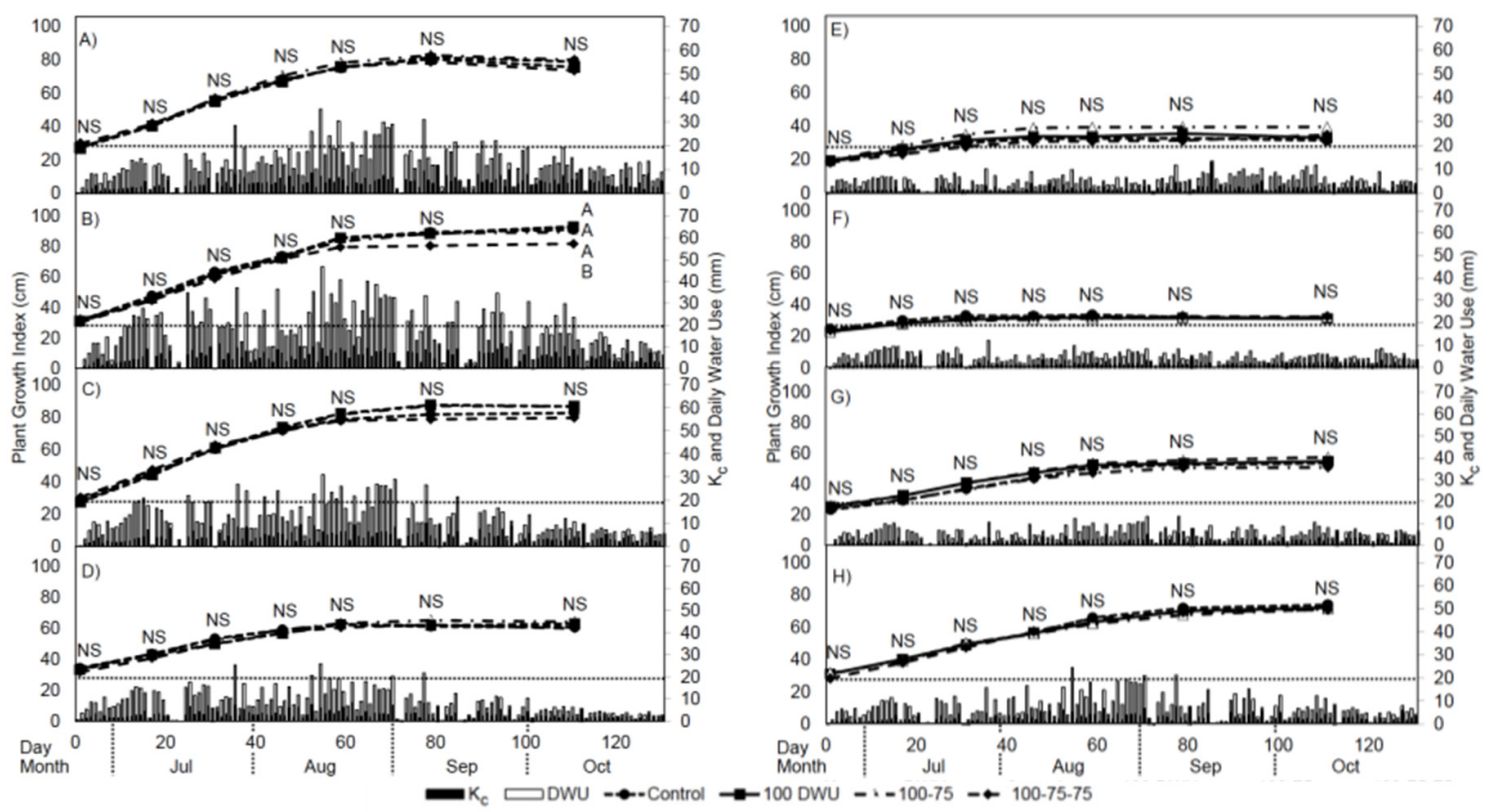

Figure 4. Plant Growth Index (GI), Daily Crop Coefficient $\left(\mathrm{K}_{\mathrm{C}}\right)$, and Daily Water Use (DWU) from 23 June (Day 1) to 31 October 2010 (Day 131) for (A) Hydrangea arborescens 'Abetwo', (B) Hydrangea paniculata 'Limelight', (C) Rhus aromatica 'Gro-Low', (D) Spiraea fritschiana 'Wilma', (E) Syringa meyeri 'Palibin', (F) Syringa xhyacinthiflora 'Evangeline', (G) Viburnum dentatum 'Ralph Senior', and (H) Weigela florida 'Alexandra' grown in 10.2 L containers. Left $y$-axis indicates PGI (lines). Control $=19 \mathrm{~mm}$.application ${ }^{-1}$; $100 \mathrm{DWU}=100 \%$ daily water use (DWU) replacement each day; 100-75DWU = 2-day cycle alternating 100\% DWU and 75\% DWU; and 100-75-75DWU = 3 day cycle with 100\% DWU replacement the first day then 2 days 75\% DWU replacement. Each day was analyzed separately (Tukey's test, $\alpha=0.05, n=18$ ). Means followed by the same letters are not different. NS = not significant. Right y-axis indicates DWU where the entire bars represent DWU $(\mathrm{mm})$ averaged from all treatments $(n=12)$; shaded portions of bars represent daily $\mathrm{K}_{\mathrm{C}}$ (DWU: $\mathrm{ET}_{0}, n=12$ ). Overhead irrigation scheduling based on highest DWU of the 8 taxa in each treatment replicate each day. ${ }^{\mathrm{y}}$ Different letters denote significant differences between treatments in order from top to bottom: Control, 100DWU, 100-75DWU, 100-75-75DWU with A associated with the greatest mean value and subsequent letters associated with lower mean values.

In both 2009 and 2010, plant GI steadily increased in June and July, slowed between August and September, and reached a plateau in September to October as new growth began hardening in preparation for winter (Figures 3 and 4). There were no differences in GI in 2009 except for H. paniculata 'Limelight' where control was smaller than 100DWU from day 42 on and smaller than 100-75-75DWU on days 42 and 74, however, these differences were fairly small (Figure 3). No growth differences were observed on any measurement date throughout 2010 except the final date where H. paniculata 'Limelight' had smaller GI for 100-75-75DWU than other treatments, again the differences were minor (Figure 4). There were no differences in shoot dry weight for the three taxa evaluated in 2010 (data not shown). 


\subsection{Crop Coefficients}

Crop coefficients $\left(\mathrm{K}_{\mathrm{C}}\right)$ varied by month across the growing season (Tables 3 and 4 ). Differences in $\mathrm{K}_{\mathrm{C}}$ and $\mathrm{K}_{\mathrm{Cadj}}$ demonstrate differences in water use efficiency due to over- or under-watering. $\mathrm{K}_{\mathrm{C}}$ or $\mathrm{K}_{\text {Cadj }}$ peaked on day 74 in 2009 (Table 3). Similarly, in 2010, the highest $\mathrm{K}_{\mathrm{C}}$ or $\mathrm{K}_{\text {Cadj }}$ was observed on days 78 to 81 depending on taxa (Table 4). When differences in $\mathrm{K}_{\mathrm{C}}$ or $\mathrm{K}_{\text {Cadj }}$ occurred in 2009, they were usually lower for one of the DWU treatments than the control although in a few instances $\mathrm{K}_{\text {Cadj }}$ was lower for the control than one of the DWU treatments (Table 3). However, there was no consistent pattern in differences. From July through October 2010, the highest $\mathrm{K}_{\text {Cadj }}$ was found for the 100-75DWU treatments in the high water use taxa, H. arborescens 'Abetwo', H. paniculata 'Limelight', and $R$. aromatica 'Gro-Low' (Table 4), which also had the highest season average DWU for these taxa (Table 2). In contrast, low and moderate water use species usually had the lowest $K_{\text {Cadj }}$ in 100-75DWU and highest $\mathrm{K}_{\mathrm{C}}$ or $\mathrm{K}_{\mathrm{Cadj}}$ in the control or 100DWU, both of these treatments received less irrigation than 100-75DWU (Table 2). $\mathrm{K}_{\mathrm{C}}$ or $\mathrm{K}_{\mathrm{Cadj}}$ was generally higher for plants receiving more water among high water users and decreased when low water users receive too much water. Using the classification system proposed by Warsaw et al. [13], A. arbutifolia 'Brilliantissima', C. sericea 'Farrow', H. arborescens 'Abetwo', H. paniculata 'Limelight', I. virginica 'Morton', P. opulifolius 'Seward', R. aromatica 'Gro-low', S. fritschiana 'Wilma', S. media 'Darsnorm', T. plicata 'Grovepli' and W. florida 'Alexandra' (2009) are high water users $\left(\mathrm{K}_{C}>3.0\right)$; $V$. dentatum 'Ralph Senior', and S. meyeri 'Palibin' are moderate water users $\left(2.0 \leq \mathrm{K}_{\mathrm{C}}<3.0\right)$; S. xhyacinthiflora 'Evangeline' and W. florida 'Alexandra' (2010) $\left(\mathrm{K}_{\mathrm{C}}<2.0\right)$ are low water users.

Table 3. Monthly crop coefficient $\left(\mathrm{K}_{\mathrm{C}}\right.$ or $\left.\mathrm{K}_{\mathrm{Cadj}}\right)$ for eight shrubs grown in $10.2 \mathrm{~L}$ containers under four irrigation treatments ${ }^{z}$ from 11 June (Day 0) through 14 October (Day 126) 2009. Control = $19 \mathrm{~mm} \cdot$ application $^{-1}\left(1.02 \mathrm{~L} \cdot\right.$ day $\left.^{-1}\right) ; 100 \mathrm{DWU}=100 \%$ daily water use (DWU) replacement each day; 100-75DWU = 2-day cycle alternating 100\% DWU and 75\% DWU; and 100-75-75DWU = 3 day cycle with $100 \%$ DWU replacement the first day then 2 days $75 \%$ DWU replacement. Overhead irrigation scheduling based on 2009) lowest DWU of the 8 taxa during each measurement period with remaining water requirement supplied by hand each day in DWU treatments as necessary.

\begin{tabular}{|c|c|c|c|c|}
\hline Month & Control & 100DWU & 100-75DWU & 100-75-75DWU \\
\hline \multicolumn{5}{|c|}{ Aronia arbutifolia 'Brilliantissima' } \\
\hline June & $2.40 \mathrm{Ab}^{\mathrm{z}}$ & $2.80 \mathrm{Aab}$ & $3.14 \mathrm{Aa}$ & $2.16 \mathrm{Ab}$ \\
\hline July & $2.42 \mathrm{Ab}$ & $2.23 \mathrm{Ab}$ & $2.02 \mathrm{Aa}$ & $2.32 \mathrm{Ab}$ \\
\hline August & $4.17 \mathrm{Aa}$ & $4.05 \mathrm{Aa}$ & $3.76 \mathrm{Aa}$ & $3.56 \mathrm{Ab}$ \\
\hline September & $3.78 \mathrm{Aab}$ & $3.09 \mathrm{Aab}$ & 3.39 Aa & $2.76 \mathrm{Ab}$ \\
\hline October & $5.22 \mathrm{Aa}$ & $3.74 \mathrm{Aab}$ & $3.50 \mathrm{Aa}$ & $5.13 \mathrm{Aa}$ \\
\hline Season & $3.60 \mathrm{~A}$ & $3.35 \mathrm{~A}$ & $3.22 \mathrm{~A}$ & $3.18 \mathrm{~A}$ \\
\hline \multicolumn{5}{|c|}{ Cornus sericea 'Farrow' } \\
\hline June & $2.58 \mathrm{Ab}$ & $2.32 \mathrm{Abc}$ & $2.34 \mathrm{Ac}$ & $2.12 \mathrm{Ac}$ \\
\hline July & $2.84 \mathrm{Ab}$ & $1.96 \mathrm{Bc}$ & $2.52 \mathrm{ABc}$ & $2.60 \mathrm{ABc}$ \\
\hline August & $5.88 \mathrm{Aa}$ & $4.82 \mathrm{Aa}$ & $6.52 \mathrm{Aa}$ & $4.56 \mathrm{Ab}$ \\
\hline September & $5.28 \mathrm{Aab}$ & $4.64 \mathrm{Aa}$ & $3.95 \mathrm{Abc}$ & $5.71 \mathrm{Aab}$ \\
\hline October & $7.35 \mathrm{Aa}$ & 4.19 Aab & $5.87 \mathrm{Aab}$ & $6.62 \mathrm{Aa}$ \\
\hline Season & $4.80 \mathrm{~A}$ & $3.71 \mathrm{~A}$ & $4.09 \mathrm{~A}$ & $4.12 \mathrm{~A}$ \\
\hline \multicolumn{5}{|c|}{ Hydrangea paniculata 'Limelight' } \\
\hline June & $2.12 \mathrm{Ac}$ & $2.02 \mathrm{Ac}$ & $2.42 \mathrm{Ac}$ & $2.11 \mathrm{Ac}$ \\
\hline July & $3.55 \mathrm{Abc}$ & $3.48 \mathrm{Ac}$ & $2.53 \mathrm{Bb}$ & $3.11 \mathrm{ABc}$ \\
\hline August & $5.72 \mathrm{Bab}$ & $8.03 \mathrm{Aa}$ & $7.24 \mathrm{ABa}$ & $6.08 \mathrm{Bb}$ \\
\hline September & $5.92 \mathrm{Aa}$ & $5.83 \mathrm{Ab}$ & $5.84 \mathrm{Aa}$ & $5.78 \mathrm{Ab}$ \\
\hline October & $6.75 \mathrm{Aa}$ & $8.35 \mathrm{Aa}$ & $7.25 \mathrm{Aa}$ & $8.96 \mathrm{Aa}$ \\
\hline Season & $4.92 \mathrm{~B}$ & $6.07 \mathrm{~A}$ & $5.35 \mathrm{AB}$ & $5.31 \mathrm{AB}$ \\
\hline \multicolumn{5}{|c|}{ Itea virginica 'Morton' } \\
\hline June & $2.00 \mathrm{ABb}$ & $1.42 \mathrm{Bc}$ & $3.05 \mathrm{Aab}$ & $2.69 \mathrm{ABa}$ \\
\hline
\end{tabular}


Table 3. Cont.

\begin{tabular}{|c|c|c|c|c|}
\hline Month & Control & 100DWU & 100-75DWU & 100-75-75DWU \\
\hline July & $2.57 \mathrm{Ab}$ & $2.40 \mathrm{Abc}$ & $2.21 \mathrm{Ab}$ & $2.52 \mathrm{Aa}$ \\
\hline August & $4.42 \mathrm{Aab}$ & $4.93 \mathrm{Aa}$ & $3.56 \mathrm{Aab}$ & $3.47 \mathrm{Aa}$ \\
\hline September & $2.61 \mathrm{Ab}$ & 3.65 Aab & $4.23 \mathrm{Aa}$ & $3.15 \mathrm{Aa}$ \\
\hline October & $6.02 \mathrm{Aa}$ & 3.05 Babc & $4.22 \mathrm{ABa}$ & $4.13 \mathrm{ABa}$ \\
\hline Season & $3.71 \mathrm{~A}$ & $3.55 \mathrm{~A}$ & $3.45 \mathrm{~A}$ & $3.21 \mathrm{~A}$ \\
\hline \multicolumn{5}{|c|}{ Physocarpus opulifolius 'Seward' } \\
\hline June & $2.43 \mathrm{Ac}$ & $2.79 \mathrm{Ab}$ & $2.25 \mathrm{Ab}$ & $2.24 \mathrm{Ab}$ \\
\hline July & $2.95 \mathrm{Abc}$ & $2.44 \mathrm{Ab}$ & $2.33 \mathrm{Ab}$ & $2.34 \mathrm{Ab}$ \\
\hline August & $5.87 \mathrm{Aa}$ & $6.59 \mathrm{Aa}$ & $5.82 \mathrm{Aa}$ & $5.53 \mathrm{Aa}$ \\
\hline September & $4.59 \mathrm{Aab}$ & $5.20 \mathrm{Aa}$ & $4.44 \mathrm{Aa}$ & $6.35 \mathrm{Aa}$ \\
\hline October & $5.74 \mathrm{Aa}$ & $6.25 \mathrm{Aa}$ & $5.75 \mathrm{Aa}$ & $7.13 \mathrm{Aa}$ \\
\hline Season & $4.56 \mathrm{~A}$ & $5.06 \mathrm{~A}$ & $4.29 \mathrm{~A}$ & $4.77 \mathrm{~A}$ \\
\hline \multicolumn{5}{|c|}{ Spiraea media 'Darsnorm' } \\
\hline June & $2.14 \mathrm{Ab}$ & $2.10 \mathrm{Ab}$ & $3.01 \mathrm{Abc}$ & $2.88 \mathrm{Abc}$ \\
\hline July & $2.85 \mathrm{Ab}$ & $2.19 \mathrm{ABb}$ & $2.30 \mathrm{ABC}$ & $1.97 \mathrm{Bc}$ \\
\hline August & $5.05 \mathrm{Aa}$ & $4.39 \mathrm{Aa}$ & 4.89 Aab & $3.49 \mathrm{Abc}$ \\
\hline September & $2.88 \mathrm{Ab}$ & $4.12 \mathrm{Aa}$ & $3.31 \mathrm{Abc}$ & $4.03 \mathrm{Ab}$ \\
\hline October & $5.92 \mathrm{Aa}$ & 3.67 Aab & $5.47 \mathrm{Aa}$ & $6.45 \mathrm{Aa}$ \\
\hline Season & $3.94 \mathrm{~A}$ & $3.51 \mathrm{~A}$ & $3.92 \mathrm{~A}$ & $3.78 \mathrm{~A}$ \\
\hline \multicolumn{5}{|c|}{ Thuja plicata 'Grovepli' } \\
\hline June & $2.33 \mathrm{ABb}$ & $2.14 \mathrm{Ba}$ & $2.68 \mathrm{ABab}$ & $3.74 \mathrm{Ab}$ \\
\hline July & $2.72 \mathrm{Aab}$ & $2.59 \mathrm{Aa}$ & $2.25 \mathrm{Ab}$ & $2.79 \mathrm{Ab}$ \\
\hline August & $4.42 \mathrm{Aab}$ & $4.06 \mathrm{Aa}$ & $3.30 \mathrm{Aab}$ & $3.26 \mathrm{Ab}$ \\
\hline September & $5.16 \mathrm{Aa}$ & $4.08 \mathrm{Aa}$ & $2.74 \mathrm{Aab}$ & $3.22 \mathrm{Ab}$ \\
\hline October & $4.99 \mathrm{Aa}$ & $3.25 \mathrm{Aa}$ & $3.87 \mathrm{Aa}$ & $5.62 \mathrm{Aa}$ \\
\hline Season & $3.97 \mathrm{~A}$ & $3.39 \mathrm{AB}$ & $3.00 \mathrm{~B}$ & $3.97 \mathrm{~A}$ \\
\hline \multicolumn{5}{|c|}{ Weigela florida 'Alexandra' } \\
\hline June & $2.40 \mathrm{ABC}$ & $1.64 \mathrm{Bb}$ & $2.27 \mathrm{ABb}$ & 2.88 Acd \\
\hline July & $2.91 \mathrm{Abc}$ & $2.44 \mathrm{ABb}$ & $2.18 \mathrm{Bb}$ & $2.65 \mathrm{ABd}$ \\
\hline August & $4.43 \mathrm{Aab}$ & $4.89 \mathrm{Aa}$ & 3.97 Aab & $4.37 \mathrm{Abc}$ \\
\hline September & 3.48 Babc & $5.24 \mathrm{ABa}$ & $4.37 \mathrm{ABa}$ & $5.38 \mathrm{Ab}$ \\
\hline October & $4.73 \mathrm{Ba}$ & $5.92 \mathrm{ABa}$ & $5.31 \mathrm{ABa}$ & $7.48 \mathrm{Aa}$ \\
\hline Season & $3.69 \mathrm{~B}$ & $4.30 \mathrm{AB}$ & 3.65 B & $4.70 \mathrm{~A}$ \\
\hline
\end{tabular}

${ }^{\mathrm{z}}$ Means followed by the same uppercase letters within rows are not different; means followed by the same lowercase letters within columns by taxa are not different by Tukey's Test $(\alpha=0.05)$, Jun, Jul, September, October: $n=18$, Aug $n=36$, Season $n=108$.

Table 4. Monthly crop coefficient $\left(\mathrm{K}_{\mathrm{C}}\right.$ or $\mathrm{K}_{\mathrm{Cadj}}$ ) for eight shrubs grown in $10.2 \mathrm{~L}$ containers under four irrigation treatments ${ }^{\mathrm{z}}$ from 23 June (Day 0) through 31 October (Day 131) 2010. Control = $19 \mathrm{~mm} \cdot$ application $^{-1}\left(1.02{\left.\mathrm{~L} \cdot \text { day }^{-1}\right)}^{-1}\right.$; 100DWU $=100 \%$ daily water use (DWU) replacement each day; 100-75DWU = 2-day cycle alternating 100\% DWU and 75\% DWU; and 100-75-75DWU = 3-day cycle with 100\% DWU replacement the first day then 2 days 75\% DWU replacement. Overhead irrigation scheduling based on 2009) lowest DWU of the 8 taxa during each measurement period with remaining water requirement supplied by hand each day in DWU treatments as necessary.

\begin{tabular}{ccccc}
\hline Month & Control & 100DWU & 100-75DWU & 100-75-75DWU \\
\hline \multicolumn{5}{c}{ Hydrangea arborescens 'Abetwo' } \\
\hline June & $1.56 \mathrm{ABb}^{\mathrm{z}}$ & $1.55 \mathrm{ABb}$ & $1.96 \mathrm{Ac}$ & $0.79 \mathrm{Bb}$ \\
July & $3.69 \mathrm{Aa}$ & $2.26 \mathrm{Bb}$ & $4.73 \mathrm{Ab}$ & $1.92 \mathrm{Bab}$ \\
August & $5.07 \mathrm{Ba}$ & $3.83 \mathrm{BCa}$ & $7.83 \mathrm{Aa}$ & $2.92 \mathrm{Ca}$ \\
September & $4.82 \mathrm{Ba}$ & $4.00 \mathrm{BCa}$ & $6.90 \mathrm{Aa}$ & $2.94 \mathrm{Ca}$ \\
October & $4.09 \mathrm{Ba}$ & $4.25 \mathrm{Ba}$ & $6.24 \mathrm{Aab}$ & $2.39 \mathrm{Cab}$ \\
Season & $4.24 \mathrm{~B}$ & $3.51 \mathrm{C}$ & $6.09 \mathrm{~A}$ & $2.51 \mathrm{D}$ \\
\hline
\end{tabular}


Table 4. Cont.

\begin{tabular}{|c|c|c|c|c|}
\hline Month & Control & 100DWU & 100-75DWU & 100-75-75DWU \\
\hline \multicolumn{5}{|c|}{ Hydrangea paniculata 'Limelight' } \\
\hline June & $1.91 \mathrm{ABb}$ & $2.08 \mathrm{ABb}$ & $2.70 \mathrm{Ab}$ & $1.27 \mathrm{Bb}$ \\
\hline July & $3.94 \mathrm{Ba}$ & $5.13 \mathrm{ABa}$ & $6.67 \mathrm{Aa}$ & $3.81 \mathrm{Ba}$ \\
\hline August & $4.79 \mathrm{Ba}$ & $6.82 \mathrm{Aa}$ & $7.92 \mathrm{Aa}$ & $5.03 \mathrm{Ba}$ \\
\hline September & $4.99 \mathrm{ABa}$ & $6.14 \mathrm{ABa}$ & $6.89 \mathrm{Aa}$ & $4.58 \mathrm{Ba}$ \\
\hline October & $\begin{array}{c}4.71 \mathrm{ABa} \\
82 \mathrm{AB}\end{array}$ & $4.90 \mathrm{ABa}$ & $6.21 \mathrm{Aa}$ & $3.51 \mathrm{Bab}$ \\
\hline Season & $4.41 \mathrm{C}$ & $5.46 \mathrm{~B}$ & $6.64 \mathrm{~A}$ & $4.04 \mathrm{C}$ \\
\hline \multicolumn{5}{|c|}{ Rhus aromatica 'Grow-low' } \\
\hline June & $2.26 \mathrm{Ac}$ & $1.96 \mathrm{ABb}$ & $1.99 \mathrm{ABC}$ & $0.95 \mathrm{Bb}$ \\
\hline July & 4.67 Aab & $3.66 \mathrm{ABa}$ & $4.90 \mathrm{Aab}$ & $2.38 \mathrm{Bab}$ \\
\hline August & $5.67 \mathrm{Aa}$ & 4.67 ABa & $5.66 \mathrm{Aa}$ & $3.76 \mathrm{Ba}$ \\
\hline September & $4.50 \mathrm{ABab}$ & $4.43 \mathrm{ABa}$ & $4.85 \mathrm{Aab}$ & $3.24 \mathrm{Ba}$ \\
\hline October & $2.27 \mathrm{ABc}$ & $3.69 \mathrm{Aa}$ & $3.82 \mathrm{Ab}$ & 2.49 Bab \\
\hline Season & $4.21 \mathrm{~A}$ & $3.98 \mathrm{~A}$ & $4.63 \mathrm{~A}$ & $2.87 \mathrm{~B}$ \\
\hline \multicolumn{5}{|c|}{ Spiraea fritschiana 'Wilma' } \\
\hline June & $1.94 \mathrm{Ab}$ & $1.84 \mathrm{Ac}$ & $1.42 \mathrm{ABb}$ & $0.58 \mathrm{Bc}$ \\
\hline July & $3.83 \mathrm{Aa}$ & $3.92 \mathrm{Aab}$ & $3.19 \mathrm{Aa}$ & $1.82 \mathrm{Bab}$ \\
\hline August & $2.45 \mathrm{Bab}$ & $4.87 \mathrm{Aa}$ & $3.58 \mathrm{Ba}$ & $2.38 \mathrm{Ba}$ \\
\hline September & $3.00 \mathrm{Bab}$ & $4.46 \mathrm{Aa}$ & $2.44 \mathrm{Bab}$ & $1.80 \mathrm{Bab}$ \\
\hline October & $2.24 \mathrm{Ab}$ & $2.44 \mathrm{Abc}$ & $1.85 \mathrm{ABb}$ & $1.21 \mathrm{Bbc}$ \\
\hline Season & $2.76 \mathrm{~B}$ & $3.74 \mathrm{~A}$ & $2.70 \mathrm{~B}$ & $1.71 \mathrm{C}$ \\
\hline \multicolumn{5}{|c|}{ Syringa meyeri 'Palibin' } \\
\hline June & 1.11 Aab & $1.60 \mathrm{Ac}$ & $0.89 \mathrm{Ab}$ & $1.06 \mathrm{Aa}$ \\
\hline July & $1.77 \mathrm{Aa}$ & $1.72 \mathrm{Abc}$ & $0.98 \mathrm{Bb}$ & $1.39 \mathrm{ABa}$ \\
\hline August & $0.58 \mathrm{Cb}$ & $3.02 \mathrm{Aab}$ & $1.05 \mathrm{BCb}$ & $1.65 \mathrm{Ba}$ \\
\hline September & $1.95 \mathrm{Aa}$ & $3.15 \mathrm{Aa}$ & $1.97 \mathrm{Aa}$ & $2.08 \mathrm{Aa}$ \\
\hline October & $1.69 \mathrm{Bab}$ & $3.02 \mathrm{Aab}$ & $1.54 \mathrm{Bab}$ & $2.34 \mathrm{ABa}$ \\
\hline Season & $1.45 \mathrm{BC}$ & $2.67 \mathrm{~A}$ & $1.31 \mathrm{C}$ & $1.83 \mathrm{~B}$ \\
\hline \multicolumn{5}{|c|}{ Syringa xhyacinthiflora 'Evangeline' } \\
\hline June & $2.02 \mathrm{Ab}$ & $0.81 \mathrm{Ba}$ & $1.06 \mathrm{Ba}$ & $1.01 \mathrm{Ba}$ \\
\hline July & $3.43 \mathrm{Aab}$ & $0.82 \mathrm{Ba}$ & $1.25 \mathrm{Ba}$ & $1.20 \mathrm{Ba}$ \\
\hline August & $3.53 \mathrm{Aab}$ & $0.86 \mathrm{Ba}$ & $1.24 \mathrm{Ba}$ & $0.92 \mathrm{Ba}$ \\
\hline September & $3.91 \mathrm{Aab}$ & $0.92 \mathrm{Ba}$ & $1.39 \mathrm{Ba}$ & $0.82 \mathrm{Ba}$ \\
\hline October & $4.50 \mathrm{Aa}$ & $1.07 \mathrm{Ba}$ & $1.49 \mathrm{Ba}$ & $1.19 \mathrm{Ba}$ \\
\hline Season & $3.76 \mathrm{~A}$ & $0.92 \mathrm{~B}$ & $1.33 \mathrm{~B}$ & $1.03 \mathrm{~B}$ \\
\hline \multicolumn{5}{|c|}{ Viburnum dentatum 'Ralph Senior' } \\
\hline June & $0.98 \mathrm{Ab}$ & $1.43 \mathrm{Ab}$ & $0.74 \mathrm{Ac}$ & $1.56 \mathrm{Aa}$ \\
\hline July & $1.41 \mathrm{Bb}$ & $1.74 \mathrm{Bb}$ & $1.24 \mathrm{Bbc}$ & $2.39 \mathrm{Aa}$ \\
\hline August & $2.20 \mathrm{Aa}$ & $2.23 \mathrm{Aab}$ & $1.73 \mathrm{Aab}$ & $2.00 \mathrm{Aa}$ \\
\hline September & $2.10 \mathrm{Aa}$ & $2.72 \mathrm{Aab}$ & $2.16 \mathrm{Aa}$ & $2.40 \mathrm{Aa}$ \\
\hline October & $2.23 \mathrm{Ba}$ & $3.52 \mathrm{Aa}$ & 1.87 Bab & $2.44 \mathrm{Ba}$ \\
\hline Season & $1.96 \mathrm{BC}$ & $2.50 \mathrm{~A}$ & $1.69 \mathrm{C}$ & $2.26 \mathrm{AB}$ \\
\hline \multicolumn{5}{|c|}{ Weigela florida 'Alexandra' } \\
\hline June & $1.45 \mathrm{Ac}$ & $0.83 \mathrm{Ac}$ & $1.09 \mathrm{Ab}$ & $1.47 \mathrm{Ab}$ \\
\hline July & $2.75 \mathrm{Abc}$ & $1.33 \mathrm{Bbc}$ & $1.78 \mathrm{Bab}$ & $2.78 \mathrm{Aab}$ \\
\hline August & $4.53 \mathrm{Aa}$ & 2.33 Bab & $2.18 \mathrm{Ba}$ & $4.62 \mathrm{Aa}$ \\
\hline September & 4.14 Aab & 2.72 BCa & $2.35 \mathrm{Ca}$ & $3.90 \mathrm{ABa}$ \\
\hline October & $3.93 \mathrm{Aab}$ & 1.91 Babc & $2.21 \mathrm{Ba}$ & 3.38 Aab \\
\hline Season & $3.69 \mathrm{~A}$ & $1.99 \mathrm{~B}$ & $2.08 \mathrm{~B}$ & $3.57 \mathrm{~A}$ \\
\hline
\end{tabular}

${ }^{z}$ Means followed by the same uppercase letters within rows are not different; means followed by the same lowercase letters within columns by taxa are not different by Tukey's Test $(\alpha=0.05)$, Jun, Jul, September, October: $n=18$, August $n=36$, Season $n=108$. 


\subsection{Leachate Electrical Conductivity and $p H$}

Leachate EC was within acceptable ranges for all treatments and dates for both years except day 2 in 2010 when it was slightly higher than recommended [18]. Differences in EC due to treatment occurred only for one taxon for one measurement date in each year (data not shown). In 2009, EC for all taxa and treatments was $0.37 \pm 0.03,0.83 \pm 0.05$, and $0.82 \pm 0.04 \mathrm{dS} \cdot \mathrm{m}^{-1}$ (mean $\pm \mathrm{SE}$ ) on days 16, 57, and 120, respectively. In 2010, EC was $2.41 \pm 0.12,1.73 \pm 0.14,1.03 \pm 0.15,0.70 \pm 0.05,0.66 \pm 0.06$, and $0.76 \pm 0.03 \mathrm{dS} \cdot \mathrm{m}^{-1}$ (mean $\pm \mathrm{SE}$ ) on days $2,17,34,59,79$, and 111 , respectively.

In 2009, the differences in substrate leachate $\mathrm{pH}$ due to treatment were less than 0.5 units and occurred only for C. sericea and W. florida on day 57 and I. virginica on days 57 and 120 (data not shown). Substrate leachate $\mathrm{pH}$ for all taxa and treatments in 2009 was $6.76 \pm 0.03,6.76 \pm 0.05$, and $7.18 \pm 0.04$ (mean \pm SE) on days 16,57 , and 120 , respectively. There were some minor differences in $\mathrm{pH}$ due to treatment early in 2010 but after day 59 the differences in $\mathrm{pH}$ were less than 0.5 units and only for $S$. meyeri (data not shown). Substrate leachate $\mathrm{pH}$ for all taxa and treatments in 2010 was $6.19 \pm 0.05$, $6.57 \pm 0.07,7.19 \pm 0.07,7.18 \pm 0.05,7.21 \pm 0.04$, and $7.59 \pm 0.06$ (mean $\pm \mathrm{SE}$ ) on days $2,17,34,59,79$, and 111 , respectively.

\subsection{Foliar Analysis}

In 2009, foliar P and/or K concentrations were higher for at least one of the DWU treatments compared to the control for all taxa except $W$. florida 'Alexandra' on day 90 (Table 5). Additionally, W. florida 'Alexandra' had higher foliar K for 100DWU and 100-75-75DWU than control on day 63 and P. opulifolius 'Seward' had higher foliar P and K concentration for all DWU treatments than the control on day 63. In 2010, the only differences in foliar analysis were lower foliar $\mathrm{N}$ concentrations in the 100-75DWU than 100DWU for H. paniculata 'Limelight' on day 36 and lower for 100-75DWU than all other treatments for $V$. dentatum 'Ralph Senior' on day 64 (Table 6). Foliar concentrations of other nutrients were general similar among treatments in both years (data not shown).

Table 5. Foliar analysis (\% dry wt.) sampled on days 58 and 85 of five taxa grown in $10.2 \mathrm{~L}$ containers and subject to four irrigation treatments from 11 June (Day 1) to 14 October 2009 (Day 126). Control = $19 \mathrm{~mm} \cdot$ application $^{-1} ; 100 \mathrm{DWU}=100 \%$ daily water use (DWU) replacement each day; 100-75DWU = 2-day cycle alternating 100\% DWU and 75\% DWU; and 100-75-75DWU = 3-day cycle with 100\% DWU replacement the first day then 2 days 75\% DWU replacement. Overhead irrigation scheduling based on lowest DWU of the 8 taxa during each measurement period with remaining water requirement supplied by hand each day in DWU treatments as necessary. Recommendations nutrient ranges as \% dry weight for woody ornamental plants are 2-4.5 for N, 0.2-0.6 for P, and 1.5-3.5 for K [23].

\begin{tabular}{|c|c|c|c|c|}
\hline & \multicolumn{4}{|c|}{ Foliar Analysis } \\
\hline & Control $^{\mathrm{z}}$ & 100DWU & 100-75DWU & 100-75-75DWU \\
\hline & \multicolumn{4}{|c|}{ Hydrangea paniculata 'Limelight' } \\
\hline \multicolumn{5}{|l|}{ Day 58} \\
\hline $\mathrm{N}(\%)$ & $2.87 \mathrm{~A}^{\mathrm{y}}$ & $2.88 \mathrm{~A}$ & $2.99 \mathrm{~A}$ & $2.96 \mathrm{~A}$ \\
\hline $\mathrm{P}(\%)$ & $0.24 \mathrm{~A}$ & $0.29 \mathrm{~A}$ & $0.30 \mathrm{~A}$ & $0.29 \mathrm{~A}$ \\
\hline $\mathrm{K}(\%)$ & $1.65 \mathrm{~A}$ & $2.23 \mathrm{~A}$ & $2.07 \mathrm{~A}$ & $2.07 \mathrm{~A}$ \\
\hline \multicolumn{5}{|l|}{ Day 85} \\
\hline N (\%) & $2.24 \mathrm{~A}$ & $2.35 \mathrm{~A}$ & $2.38 \mathrm{~A}$ & $2.31 \mathrm{~A}$ \\
\hline $\mathrm{P}(\%)$ & $0.14 \mathrm{~B}$ & $0.17 \mathrm{AB}$ & $0.18 \mathrm{~A}$ & $0.17 \mathrm{AB}$ \\
\hline \multirow[t]{2}{*}{$\mathrm{K}(\%)$} & $0.41 \mathrm{~B}$ & $0.65 \mathrm{~A}$ & $0.61 \mathrm{AB}$ & $0.67 \mathrm{~A}$ \\
\hline & \multicolumn{4}{|c|}{ Itea virginica 'Morton' } \\
\hline Day 58 & & & & \\
\hline $\mathrm{N}(\%)$ & $2.50 \mathrm{~A}$ & $2.69 \mathrm{~A}$ & $2.46 \mathrm{~A}$ & $2.65 \mathrm{~A}$ \\
\hline $\mathrm{P}(\%)$ & $0.22 \mathrm{~A}$ & $0.22 \mathrm{~A}$ & $0.22 \mathrm{~A}$ & $0.24 \mathrm{~A}$ \\
\hline $\mathrm{K}(\%)$ & $0.65 \mathrm{~A}$ & $0.55 \mathrm{~A}$ & $0.58 \mathrm{~A}$ & $0.66 \mathrm{~A}$ \\
\hline
\end{tabular}


Table 5. Cont.

\begin{tabular}{|c|c|c|c|c|}
\hline & \multicolumn{4}{|c|}{ Foliar Analysis } \\
\hline & Control $^{z}$ & 100DWU & 100-75DWU & 100-75-75DWU \\
\hline \multicolumn{5}{|l|}{ Day 85} \\
\hline $\mathrm{N}(\%)$ & $2.37 \mathrm{~A}$ & $2.74 \mathrm{~A}$ & $2.59 \mathrm{~A}$ & $2.55 \mathrm{~A}$ \\
\hline $\mathrm{P}(\%)$ & $0.16 \mathrm{~B}$ & $0.20 \mathrm{AB}$ & $0.20 \mathrm{AB}$ & $0.21 \mathrm{~A}$ \\
\hline \multirow[t]{2}{*}{$\mathrm{K}(\%)$} & $0.48 \mathrm{~A}$ & $0.53 \mathrm{~A}$ & $0.54 \mathrm{~A}$ & $0.55 \mathrm{~A}$ \\
\hline & \multicolumn{4}{|c|}{ Physocarpus opulifolius 'Seward' } \\
\hline \multicolumn{5}{|l|}{ Day 58} \\
\hline $\mathrm{N}(\%)$ & $3.19 \mathrm{~A}$ & $3.19 \mathrm{~A}$ & $3.19 \mathrm{~A}$ & $3.33 \mathrm{~A}$ \\
\hline $\mathrm{P}(\%)$ & $0.31 \mathrm{~B}$ & $0.37 \mathrm{~A}$ & $0.37 \mathrm{~A}$ & $0.39 \mathrm{~A}$ \\
\hline $\mathrm{K}(\%)$ & $1.09 \mathrm{~B}$ & $1.46 \mathrm{~A}$ & $1.59 \mathrm{~A}$ & $1.66 \mathrm{~A}$ \\
\hline \multicolumn{5}{|l|}{ Day 85} \\
\hline $\mathrm{N}(\%)$ & $2.15 \mathrm{~A}$ & $2.20 \mathrm{~A}$ & $2.28 \mathrm{~A}$ & $2.28 \mathrm{~A}$ \\
\hline $\mathrm{P}(\%)$ & $0.21 \mathrm{~B}$ & $0.23 \mathrm{AB}$ & $0.25 \mathrm{~A}$ & $0.24 \mathrm{~A}$ \\
\hline \multirow[t]{2}{*}{$\mathrm{K}(\%)$} & $0.38 \mathrm{~B}$ & $0.41 \mathrm{~A}$ & $0.45 \mathrm{~A}$ & $0.42 \mathrm{~A}$ \\
\hline & \multicolumn{4}{|c|}{ Spiraea media 'Darsnorm' } \\
\hline \multicolumn{5}{|l|}{ Day 58} \\
\hline $\mathrm{N}(\%)$ & $2.27 \mathrm{~A}$ & $2.38 \mathrm{~A}$ & $2.23 \mathrm{~A}$ & $2.42 \mathrm{~A}$ \\
\hline $\mathrm{P}(\%)$ & $0.63 \mathrm{~A}$ & $0.67 \mathrm{~A}$ & $0.66 \mathrm{~A}$ & $0.66 \mathrm{~A}$ \\
\hline $\mathrm{K}(\%)$ & $1.26 \mathrm{~A}$ & $1.63 \mathrm{~A}$ & $1.66 \mathrm{~A}$ & $1.64 \mathrm{~A}$ \\
\hline \multicolumn{5}{|l|}{ Day 85} \\
\hline $\mathrm{N}(\%)$ & $2.50 \mathrm{~A}$ & $2.70 \mathrm{~A}$ & $2.63 \mathrm{~A}$ & $2.74 \mathrm{~A}$ \\
\hline $\mathrm{P}(\%)$ & $0.72 \mathrm{~B}$ & $0.81 \mathrm{AB}$ & $0.87 \mathrm{~A}$ & $0.81 \mathrm{AB}$ \\
\hline \multirow[t]{2}{*}{$\mathrm{K}(\%)$} & $1.14 \mathrm{~B}$ & $1.39 \mathrm{AB}$ & $1.52 \mathrm{~A}$ & $1.32 \mathrm{AB}$ \\
\hline & \multicolumn{4}{|c|}{ Weigela florida 'Alexandra' } \\
\hline \multicolumn{5}{|l|}{ Day 58} \\
\hline $\mathrm{N}(\%)$ & $2.05 \mathrm{~A}$ & $2.12 \mathrm{~A}$ & $2.20 \mathrm{~A}$ & $2.21 \mathrm{~A}$ \\
\hline $\mathrm{P}(\%)$ & $0.34 \mathrm{~A}$ & $0.37 \mathrm{~A}$ & $0.38 \mathrm{~A}$ & $0.39 \mathrm{~A}$ \\
\hline $\mathrm{K}(\%)$ & $1.91 \mathrm{~B}$ & $2.38 \mathrm{~A}$ & $2.31 \mathrm{AB}$ & $2.55 \mathrm{~A}$ \\
\hline \multicolumn{5}{|l|}{ Day 85} \\
\hline $\mathrm{N}(\%)$ & $2.18 \mathrm{~A}$ & $2.02 \mathrm{~A}$ & $2.06 \mathrm{~A}$ & $2.05 \mathrm{~A}$ \\
\hline $\mathrm{P}(\%)$ & $0.30 \mathrm{~A}$ & $0.35 \mathrm{~A}$ & $0.38 \mathrm{~A}$ & $0.40 \mathrm{~A}$ \\
\hline $\mathrm{K}(\%)$ & $0.98 \mathrm{~A}$ & $1.18 \mathrm{~A}$ & $1.11 \mathrm{~A}$ & $1.21 \mathrm{~A}$ \\
\hline
\end{tabular}

$\mathrm{y}$ Means followed by the same letter within rows are not different by Tukey's Test $(\alpha=0.05, n=3$ ).

Table 6. Foliar analysis (\% dry wt.) sampled on days 36 and 64 of six taxa grown in 10.2 L containers and subject to four irrigation treatments from 23 June (Day 1) to 31 October 2010 (Day 131). Control = $19 \mathrm{~mm} \cdot$ application $^{-1} ; 100 \mathrm{DWU}=100 \%$ daily water use (DWU) replacement each day; 100-75DWU = 2-day cycle alternating 100\% DWU and 75\% DWU; and 100-75-75DWU = 3-day cycle with 100\% DWU replacement the first day then 2 days $75 \%$ DWU replacement. Overhead irrigation scheduling based on highest DWU of the 8 taxa in each treatment replicate each day. Recommendations nutrient ranges as $\%$ dry weight for woody ornamental plants are 2-4.5 for N, 0.2-0.6 for P, and 1.5-3.5 for K [23].

\begin{tabular}{|c|c|c|c|c|}
\hline & \multicolumn{4}{|c|}{ Foliar Analysis } \\
\hline & Control $^{\mathrm{z}}$ & 100DWU & 100-75DWU & 100-75-75DWU \\
\hline & \multicolumn{4}{|c|}{ Hydrangea arborescens 'Abetwo' } \\
\hline \multicolumn{5}{|l|}{ Day 36} \\
\hline $\mathrm{N}(\%)$ & $2.69 \mathrm{~A}^{\mathrm{y}}$ & $2.73 \mathrm{~A}$ & $2.72 \mathrm{~A}$ & $2.60 \mathrm{~A}$ \\
\hline $\mathrm{P}(\%)$ & $0.26 \mathrm{~A}$ & $0.32 \mathrm{~A}$ & $0.32 \mathrm{~A}$ & $0.32 \mathrm{~A}$ \\
\hline $\mathrm{K}(\%)$ & $1.09 \mathrm{~A}$ & $1.47 \mathrm{~A}$ & $1.46 \mathrm{~A}$ & $1.44 \mathrm{~A}$ \\
\hline \multicolumn{5}{|l|}{ Day 64} \\
\hline N (\%) & $1.72 \mathrm{~A}$ & $1.58 \mathrm{~A}$ & $1.59 \mathrm{~A}$ & $1.33 \mathrm{~A}$ \\
\hline $\mathrm{P}(\%)$ & $0.18 \mathrm{~A}$ & $0.21 \mathrm{~A}$ & $0.20 \mathrm{~A}$ & $0.23 \mathrm{~A}$ \\
\hline $\mathrm{K}(\%)$ & $1.09 \mathrm{~A}$ & $1.47 \mathrm{~A}$ & $1.46 \mathrm{~A}$ & $1.44 \mathrm{~A}$ \\
\hline
\end{tabular}


Table 6. Cont.

\begin{tabular}{|c|c|c|c|c|}
\hline & \multicolumn{4}{|c|}{ Foliar Analysis } \\
\hline & Control $^{\mathrm{z}}$ & 100DWU & 100-75DWU & 100-75-75DWU \\
\hline & \multicolumn{4}{|c|}{ Hydrangea paniculata 'Limelight' } \\
\hline \multicolumn{5}{|l|}{ Day 36} \\
\hline $\mathrm{N}(\%)$ & $2.60 \mathrm{AB}$ & $2.79 \mathrm{~A}$ & $2.40 \mathrm{~B}$ & $2.52 \mathrm{AB}$ \\
\hline $\mathrm{P}(\%)$ & $0.25 \mathrm{~A}$ & $0.27 \mathrm{~A}$ & $0.26 \mathrm{~A}$ & $0.29 \mathrm{~A}$ \\
\hline $\mathrm{K}(\%)$ & $1.56 \mathrm{~A}$ & $1.68 \mathrm{~A}$ & $1.57 \mathrm{~A}$ & $1.81 \mathrm{~A}$ \\
\hline \multicolumn{5}{|l|}{ Day 64} \\
\hline $\mathrm{N}(\%)$ & $1.72 \mathrm{~A}$ & $1.58 \mathrm{~A}$ & $1.59 \mathrm{~A}$ & $1.33 \mathrm{~A}$ \\
\hline $\mathrm{P}(\%)$ & $0.17 \mathrm{~A}$ & $0.16 \mathrm{~A}$ & $0.15 \mathrm{~A}$ & $0.18 \mathrm{~A}$ \\
\hline \multirow[t]{2}{*}{$\mathrm{K}(\%)$} & $0.88 \mathrm{~A}$ & $0.92 \mathrm{~A}$ & $0.74 \mathrm{~A}$ & $0.95 \mathrm{~A}$ \\
\hline & \multicolumn{4}{|c|}{ Rhus aromatica 'Gro-low' } \\
\hline \multicolumn{5}{|l|}{ Day 36} \\
\hline $\mathrm{N}(\%)$ & $1.95 \mathrm{~A}$ & $2.02 \mathrm{~A}$ & $2.05 \mathrm{~A}$ & $1.84 \mathrm{~A}$ \\
\hline $\mathrm{P}(\%)$ & $0.29 \mathrm{~A}$ & $0.30 \mathrm{~A}$ & $0.30 \mathrm{~A}$ & $0.29 \mathrm{~A}$ \\
\hline $\mathrm{K}(\%)$ & $1.84 \mathrm{~A}$ & $2.02 \mathrm{~A}$ & $2.05 \mathrm{~A}$ & $1.84 \mathrm{~A}$ \\
\hline \multicolumn{5}{|l|}{ Day 64} \\
\hline $\mathrm{N}(\%)$ & $1.76 \mathrm{~A}$ & $1.65 \mathrm{~A}$ & $1.79 \mathrm{~A}$ & $1.55 \mathrm{~A}$ \\
\hline $\mathrm{P}(\%)$ & $0.20 \mathrm{~A}$ & $0.20 \mathrm{~A}$ & $0.20 \mathrm{~A}$ & $0.19 \mathrm{~A}$ \\
\hline \multirow[t]{2}{*}{$\mathrm{K}(\%)$} & $0.52 \mathrm{~A}$ & $0.72 \mathrm{~A}$ & $0.60 \mathrm{~A}$ & $0.54 \mathrm{~A}$ \\
\hline & \multicolumn{4}{|c|}{ Spiraea fritschiana 'Wilma' } \\
\hline \multicolumn{5}{|l|}{ Day 36} \\
\hline $\mathrm{N}(\%)$ & $3.17 \mathrm{~A}$ & $3.17 \mathrm{~A}$ & $3.00 \mathrm{~A}$ & $3.08 \mathrm{~A}$ \\
\hline $\mathrm{P}(\%)$ & $0.47 \mathrm{~A}$ & $0.41 \mathrm{~A}$ & $0.51 \mathrm{~A}$ & $0.43 \mathrm{~A}$ \\
\hline $\mathrm{K}(\%)$ & $1.26 \mathrm{~A}$ & $1.12 \mathrm{~A}$ & $1.09 \mathrm{~A}$ & $1.23 \mathrm{~A}$ \\
\hline \multicolumn{5}{|l|}{ Day 64} \\
\hline $\mathrm{N}(\%)$ & $2.81 \mathrm{~A}$ & $2.66 \mathrm{~A}$ & $2.61 \mathrm{~A}$ & $2.51 \mathrm{~A}$ \\
\hline $\mathrm{P}(\%)$ & $0.34 \mathrm{~A}$ & $0.33 \mathrm{~A}$ & $0.34 \mathrm{~A}$ & $0.34 \mathrm{~A}$ \\
\hline \multirow[t]{2}{*}{$\mathrm{K}(\%)$} & $1.04 \mathrm{~A}$ & $1.01 \mathrm{~A}$ & $0.88 \mathrm{~A}$ & $1.09 \mathrm{~A}$ \\
\hline & \multicolumn{4}{|c|}{ Viburnum dentatum 'Ralph Senior' } \\
\hline \multicolumn{5}{|l|}{ Day 36} \\
\hline $\mathrm{N}(\%)$ & $2.18 \mathrm{~A}$ & $2.23 \mathrm{~A}$ & $2.13 \mathrm{~A}$ & $2.11 \mathrm{~A}$ \\
\hline $\mathrm{P}(\%)$ & $0.31 \mathrm{~A}$ & $0.31 \mathrm{~A}$ & $0.32 \mathrm{~A}$ & $0.31 \mathrm{~A}$ \\
\hline $\mathrm{K}(\%)$ & $1.61 \mathrm{~A}$ & $1.85 \mathrm{~A}$ & $1.81 \mathrm{~A}$ & $1.93 \mathrm{~A}$ \\
\hline \multicolumn{5}{|l|}{ Day 64} \\
\hline $\mathrm{N}(\%)$ & $2.37 \mathrm{~A}$ & $2.32 \mathrm{~A}$ & $1.80 \mathrm{~B}$ & $2.31 \mathrm{~A}$ \\
\hline $\mathrm{P}(\%)$ & $0.31 \mathrm{~A}$ & $0.26 \mathrm{~A}$ & $0.25 \mathrm{~A}$ & $0.29 \mathrm{~A}$ \\
\hline \multirow[t]{2}{*}{$\mathrm{K}(\%)$} & $1.58 \mathrm{~A}$ & $1.45 \mathrm{~A}$ & $1.39 \mathrm{~A}$ & $1.34 \mathrm{~A}$ \\
\hline & \multicolumn{4}{|c|}{ Weigela florida 'Alexandra' } \\
\hline \multicolumn{5}{|l|}{ Day 36} \\
\hline $\mathrm{N}(\%)$ & $2.12 \mathrm{~A}$ & $1.98 \mathrm{~A}$ & $1.82 \mathrm{~A}$ & $1.94 \mathrm{~A}$ \\
\hline $\mathrm{P}(\%)$ & $0.37 \mathrm{~A}$ & $0.38 \mathrm{~A}$ & $0.33 \mathrm{~A}$ & $0.39 \mathrm{~A}$ \\
\hline $\mathrm{K}(\%)$ & $1.71 \mathrm{~A}$ & $1.91 \mathrm{~A}$ & $1.67 \mathrm{~A}$ & $1.81 \mathrm{~A}$ \\
\hline \multicolumn{5}{|l|}{ Day 64} \\
\hline N (\%) & $1.89 \mathrm{~A}$ & $1.70 \mathrm{~A}$ & $1.70 \mathrm{~A}$ & $1.69 \mathrm{~A}$ \\
\hline $\mathrm{P}(\%)$ & $0.29 \mathrm{~A}$ & $0.29 \mathrm{~A}$ & $0.26 \mathrm{~A}$ & $0.29 \mathrm{~A}$ \\
\hline $\mathrm{K}(\%)$ & $1.13 \mathrm{~A}$ & $1.37 \mathrm{~A}$ & $1.19 \mathrm{~A}$ & $1.26 \mathrm{~A}$ \\
\hline
\end{tabular}

${ }^{y}$ Means followed by the same letter within rows are not different by Tukey's Test $(\alpha=0.05, n=3$ ).

\section{Discussion}

Irrigating based on DWU by taxa ensures that plants are receiving sufficient irrigation for growth without over- or under-irrigating. In 2009, the seasonal volume of irrigation applied was less for all DWU-based treatments compared to the controls, suggesting most taxa in the control treatment were over-irrigated. When intermittent sampling techniques are used to estimate DWU, as in 2009, under- or 
overestimation could result in applying too little or too much water between sampling dates. However, scheduling plants with a wide range of water use needs based on the taxa with the highest water requirement in real time, as done in 2010, resulted in greater water use and over-irrigation of a majority of the taxa. In 2010, less water was used over the season for the control and 100-75-75DWU treatments. A. arbutifolia 'Brilliantissima', C. sericea 'Farrow' and H. paniculata 'Limelight' were under-irrigated for the 100DWU on days $16,47,20$, respectively, while the other taxa were over-irrigated for the majority of the days. The two deficit irrigation treatments resulted in similar under- or over-irrigation for the same taxa. Yet despite the under- or over-irrigation as a result of sampling technique, there were very few and only minor differences in plant growth. These results and other studies demonstrate that container-grown plants are tolerant of these levels of deficit irrigation $[6,7,13,24]$ indicating elasticity in growth response to irrigation.

While differences in growth among treatments were minimal for both years, the amount of water applied in 2009 was 7 to $57 \%$ less when irrigation was determined by taxa. Since irrigation applications were based on the highest DWU in 2010, the low and moderate water use species were over-watered for most days in 2010, particularly mid-season when $\mathrm{K}_{C}$ or $\mathrm{K}_{\text {Cadj }}$ peaked for high users. This emphasizes the importance of grouping plants with similar water use classifications, as suggested by Burger et al. [24] and Warsaw et al. [13], into irrigation zones that can be scheduled more precisely.

Crop coefficients have been shown to increase as plants grow [16], and they are also affected by changes in weather or season $[16,17]$. Calendar month serves as a convenient interval to reevaluate $\mathrm{K}_{\mathrm{C}}$ for seasonal changes due to plant growth and environmental conditions [17]. In both 2009 and 2010, most taxa had the lowest $\mathrm{K}_{\mathrm{C}}$ or $\mathrm{K}_{\mathrm{Cadj}}$ in June or July when GI was low before plant canopies had covered the substrate surface. As plants neared maximum GI, $\mathrm{K}_{\mathrm{C}}$ or $\mathrm{K}_{\mathrm{Cadj}}$ was generally highest from August to October. However, while $\mathrm{K}_{\mathrm{C}}$ or $\mathrm{K}_{\mathrm{Cadj}}$ of high-water users tended to have a large increase between June and August, the increase was less pronounced in low water use taxa. In a study of 12 hardy ornamental shrubs, plant size did not influence $K_{C}$ early in the growing season but correlated with $K_{C}$ when plant size had increased by July [25]. Schuch and Burger [17] found that $K_{C}$ of container-grown shrubs was relatively consistent across warm and cool phases of a production cycle for low water-use taxa but $K_{C}$ varied by as much as 3.7 between months for taxa that were high water users. Similarly, Irmak [26] showed that $\mathrm{K}_{\mathrm{C}}$ of Viburnum odoratissimum Ker.-Gawl was higher in fall than summer. In the current study, DWU decreased for all plants from late August to October while $\mathrm{K}_{\mathrm{C}}$ showed little change. While there are limitations in accurately scheduling irrigation from $\mathrm{ET}_{0}$ using $\mathrm{K}_{\mathrm{C}}, \mathrm{K}_{\mathrm{C}}$ is still valuable for grouping ornamental plants by relative water needs. This study reveals that higher water use plants exhibit greater seasonal changes in $\mathrm{K}_{\mathrm{C}}$ as related to periods of active growth and plant size than do lower water users.

Since the control plants received the most water of any irrigation treatment in 2009, difference in foliar analysis could be attributable to either leaching nutrients from the substrate, nutrient dilution within the plant, or a combination of both [27]. This may also have been the case for H. paniculata 'Limelight' 100-75 DWU treatment in 2010 which received the most water of all treatments. The lower nutrient content for the second date in each year could be due to the time of year when nutrients may be mobilizing out of leaves and the CRF is releasing at a slower rate due to cooler temperatures and less solar radiation incident upon the black containers. Since the later samples in 2009 and 2010 were taken only 91 and 64 days after application of a 5- to 6-month CRF, it is unlikely that the fertilizer was exhausted.

Contrasting the two scheduling methods used in 2009 and 2010, intermittent DWU quantification risks over- or under-estimation of crop water needs for the interval between measurements whereas real-time estimation compensates for changes in DWU at daily resolution. Additionally, real-time irrigation scheduling using DWU have shortened the production of Gardenia jasminoides by as much $64 \%$ at one production nursery in Georgia by increasing its rate of growth [28]. Other incentives for real-time scheduling include shortened crop production windows that free up space for new crops sooner, reduced losses from disease, and increased overall crop profitability [4]. 
Because $\mathrm{K}_{C}$ values normalize for environmental variables [15], cross-season comparisons can be made for the same taxa. Two taxa were in common for both years. H. paniculata 'Limelight' was a high user in both 2009 and 2010 whereas W. florida 'Alexandra' was classified as a high-water user in 2009, but a low user in 2010. Using the same location and experimental design as the current study, Warsaw et al. [13] classified C. sericea 'Farrow', S. fritschiana 'Wilma' and W. florida 'Alexandra' as high users with $\mathrm{K}_{\mathrm{C}}=3.4,3.6$ and 3.6, respectively, similar to this study. Several taxa in this and other studies $[6,7,13,17,26]$ have seasonal $K_{C}$ above 4.0 . As suggested by Warsaw et al. [13], as additional $K_{C}$ values are determined the water use classifications may require adjustment. We propose the addition of a "very high" category with $K_{C} \geq 4.0$ as the criterion, making the high category $3.0 \leq K_{C}<4.0$. H. paniculata 'Limelight', P. opulifolius 'Seward', and W. florida 'Alexandra' (2009) would be very high users under this classification. Seasonal $K_{C}$ for the 10 new taxa in this study add to the growing number of published $K_{C}$ values for container-grown woody ornamentals $[6,7,13,17,26]$ further helping to establish indicator species for low, moderate, and high water use classifications that will aid in grouping plants into irrigation blocks based on similar water needs.

In a survey of nursery growers about the perceived benefits and limitations of wireless sensor networks, nearly half cited concerns that the systems may prove unreliable or not control irrigation correctly [29]. Likely, they worry that such complications would negatively impact plant growth and profitability. In a study of 24 ornamental shrub taxa, Warsaw et al. [13] showed only one plant in a deficit DWU treatment that grew less than the plants receiving $100 \%$ of their DWU. Their findings and those from the current study strongly suggest that a buffer exists in many ornamental plant species against light to moderate moisture deficits before growth reductions occur. Therefore, if minor malfunctions of sensing equipment or operator error should occur, losses in growth would likely be minimal or nonexistent if problems are corrected relatively quickly.

Grower-friendly systems are now being tested on commercial operations that permit multiple sensor inputs in a wireless network [30,31]. Used alone, these systems provide growers with additional data to make more informed scheduling decisions [28]. They also permit full automation of the irrigation scheduling process and have shown to reduce irrigation volume applied while increasing growth of ornamental trees in pot-in-pot production compared to "experience"-based irrigation [3]. Although widespread adoption of these systems may take several years, monitoring of every ornamental crop produced at most nurseries will not likely be economically feasible in the near future. Therefore, knowledge of relative water use classifications, derived by $\mathrm{K}_{\mathrm{C}}$ or other means, will be an essential part of effective sensor integration into existing irrigation infrastructure to help growers maximize water use savings and achieve greater crop profitability.

\section{Conclusions}

Scheduling irrigation based on plant daily water use can be used to reduce the amount of water needed for production of container-grown woody ornamentals with little or no effect on plant growth. When irrigation was applied based on daily water use for each taxon, including deficit irrigation treatments, the volume of irrigation required during the growing season was reduced between $7 \%$ and $57 \%$. Reduced irrigation resulted in higher foliar $\% \mathrm{~N}$ and $\% \mathrm{P}$ at times, most likely due to reduced leaching of nutrients out of containers. Scheduling irrigation based on the taxon with the highest water use (H. paniculata 'Limelight') resulted in over-irrigation for other taxa in the same irrigation zone, although with no practical effect on plant growth. H. paniculata 'Limelight' was also the only taxa for which there were irrigation treatments on growth, with slightly lower GI for control in 2009 and slightly lower GI for 100-75-75 in 2010. The limited effect of deficit irrigation or over-irrigation on plant growth indicates a high level of elasticity in plant response to irrigation and should be taken into consideration when discussing irrigation scheduling with practitioners. The knowledge of taxa-specific $\mathrm{K}_{\mathrm{C}}$ values will aid in grouping plants in irrigation zones based on water use to further increase water use efficiency. 
Author Contributions: Conceptualization, R.T.F.; Data curation, R.T.F.; Formal analysis, R.T.F., N.P. and B.M.C.; Funding acquisition, R.T.F.; Investigation, R.T.F. and N.A.P.; Methodology, R.T.F., N.P., B.M.C. and J.A.A.; Project administration, R.T.F.; Resources, B.M.C. and J.A.A.; Supervision, R.T.F.; Validation, R.T.F.; Visualization, R.T.F.; Writing—original draft, N.A.P.; Writing—review \& editing, R.T.F., B.M.C. and J.A.A.

Funding: This project was funded by the USDA National Institute of Food and Agriculture, Hatch project numbers MICL02473, MICL02403, MICL02274; Michigan State University Project GREEEN GR09-070, Michigan Department of Agriculture and Rural Development Horticulture Fund, and the in-kind support of plants, substrate and fertilizer from Spring Meadow Nursery, Inc., Renewed Earth LLC, and Harrell's LLC.

Acknowledgments: The authors would like to thank Aaron Warsaw, Glenn Jarrell and Max Braun for their assistance on this project.

Conflicts of Interest: The authors declare no conflict of interest.

\section{References}

1. Paudel, K.P.; Pandit, M.; Hinson, R. Irrigation water sources and irrigation application methods used by U.S. plant nursery producers. Water Resour. Res. 2016, 52, 698-712. [CrossRef]

2. Weatherspoon, D.M.; Harrell, C.C. Evaluation of drip irrigation for container production of woody landscape plants. HortScience 1980, 15, 488-489.

3. Belayneh, B.E.; Lea-Cox, J.D.; Lichtenberg, E. Costs and benefits of implementing sensor-controlled irrigaoin in a commercial pot-in-pot container nursery. HortTechnology 2013, 23, 760-769. [CrossRef]

4. Lichtenberg, E.; Majsztrik, J.; Saavoss, M. Profitability of sensor-based irrigation in greenhouse and nursery crops. HortTechnology 2013, 23, 770-774. [CrossRef]

5. Majsztrik, J.C.; Fernandez, R.T.; Fisher, P.R.; Hitchcock, D.R.; Lea-Cox, J.D.; Owen, J.S.; Oki, L.R.; White, S.A. Water use and treatment in containerized specialty crop production: A review. Water Air Soil Pollut. 2017, 228, 151. [CrossRef]

6. Pershey, N.A.; Cregg, B.M.; Andresen, J.A.; Fernandez, R.T. Irrigating based on daily water use reduces nursery runoff volume and nutrient load without reducing growth of four conifers. HortScience 2015, 50, 1553-1561. [CrossRef]

7. Warsaw, A.L.; Fernandez, R.T.; Cregg, B.M.; Andresen, J.A. Container-grown ornamental plant growth and water runoff nutrient content and volume under four irrigation treatments. HortScience 2009, 44, 1573-1580.

8. Beeson, R.C., Jr.; Arnold, M.A.; Bilderback, T.E.; Bolusky, B.; Chandler, S.; Gramling, H.M.; Lea-Cox, J.D.; Harris, J.R.; Klinger, P.J.; Mathers, H.M.; et al. Strategic vision of container nursery irrigation in the next ten years. J. Environ. Hortic. 2004, 22, 113-115.

9. Knox, J.W.; Kay, M.G.; Weatherhead, E.K. Water regulation, crop production and agricultural water management: Understanding farmer perspectives on irrigation efficiency. Agr. Water Manag. 2012, 108, 3-8. [CrossRef]

10. O'Neill, M.P.; Dobrowolski, J.P. Water and agriculture in a changing climate. HortScience 2011, 46, $155-157$. [CrossRef]

11. Million, J.; Yeager, T.H.; Albano, J. Consequences of excessive overhead irrigation on runoff during container production of sweet viburnum. J. Environ. Hortic. 2007, 25, 117-125. [CrossRef]

12. Tyler, H.H.; Warren, S.L.; Bilderback, T.E. Reduced leaching fractions improve irrigation use efficiency and nutrient efficacy. J. Environ. Hortic. 1996, 14, 199-204.

13. Warsaw, A.L.; Fernandez, R.T.; Cregg, B.M.; Andresen, J.A. Water conservation, growth, and water use efficiency of container-grown woody ornamentals irrigated based on daily water use. HortScience 2009, 44, 1308-1318. [CrossRef]

14. Nemali, K.S.; van Iersel, M.W. An automated system for controlling drought stress and irrigation in potted plants. Sci. Hortic. 2006, 110, 292-297. [CrossRef]

15. Allen, R.G.; Pereira, L.S.; Raes, D.; Smith, M. Crop Evapotranspiration: Guidelines for Computing Crop Water Requirements; Irrigation and Drainage Paper No. 56; FAO: Rome, Italy, 1998.

16. Niu, G.; Rodriguez, D.S.; Cabrera, R.; McKenney, C.; Mackay, W. Determining water use and crop coefficients of five woody landscape plants. J. Environ. Hortic. 2006, 24, 160-165.

17. Schuch, U.K.; Burger, D.W. Water use and crop coefficients of woody ornamentals in containers. J. Am. Soc. Hortic. Sci. 1997, 122, 727-734. [CrossRef] 
18. Yeager, T.H. Implementation Guide for Container-Grown Plant Interim Measure; EDIS Document ENH-895; Institute of Food and Agricultural Sciences, University of Florida: Gainesville, FL, USA, 2003.

19. Michigan State University. Enviro-Weather; Michigan State University: East Lansing, MI, USA, 2011.

20. Dudek, T.A.; Fernandez, R.T. Conducting a Water Application Uniformity Evaluation for an Overhead Sprinkler Irrigation System in the Nursery; MSUE Factsheet 6-4; Michigan State University: East Lansing, MI, USA, 2012.

21. Wright, R.D. The pour-through nutrient extraction procedure. HortScience 1986, 21, 227-229.

22. Horwitz, W. Official Methods of Analysis of AOAC International, 18th ed.; AOAC: Gaithersburg, MD, USA, 2005.

23. Plank, C.O. Plant Analysis Handbook of Georgia. The University of Georgia. College of Agricultural and Environmental Sciences. Cooperative Extension Service. Available online: http://aesl.ces.uga.edu/ publications/plant/contable.asp\#floral (accessed on 2 July 2019).

24. Burger, D.W.; Hartin, J.S.; Hodel, D.R.; Lukaszewski, T.A.; Tjosvold, S.A.; Wagner, S.A. Water use in California's ornamental nurseries. Calif. Agric. 1987, 41, 7-8.

25. Grant, O.M.; Davies, M.J.; Longbottom, H.; Harrison-Murray, R. Evapotranspiration of container ornamental shrubs; modeling crop-specific factors for a diverse range of crops. Irrig. Sci. 2012, 30, 1-12. [CrossRef]

26. Irmak, S. Crop evapotranspiration and crop coefficients of Viburnum odoratissimum (Ker.-Gawl). App. Eng. Agric. 2005, 21, 371-381. [CrossRef]

27. Jarrell, W.M.; Whaley, S.J.; Miraftabi, B. Slow-release fertilizer and water management with container-grown Ligustrum texanum. Sci. Hortic. 1983, 19, 177-190. [CrossRef]

28. Chappell, M.; Dove, S.K.; van Iersel, M.W.; Thomas, P.A.; Ruter, J. Implementation of wireless sensor networks for irrigation control in three container nurseries. HortTechnology 2013, 23, 747-753. [CrossRef]

29. Majsztrik, J.; Lichtenberg, E.; Saavoss, M. Ornamental grower perceptions of wireless irrigation sensor networks: Results from a national survey. HortTechnology 2013, 23, 775-782. [CrossRef]

30. Lea-Cox, J.D.; Ristvey, A.G.; Arguedas Rodriguez, F.; Ross, D.S.; Anhalt, J.; Kantor, G. A low-cost multihop wireless sensor network, enabling real-time management of environmental data for the greenhouse and nursery industry. Acta Hortic. 2008, 801, 523-530. [CrossRef]

31. Lea-Cox, J.D.; Bauerle, W.L.; van Iersel, M.W.; Kantor, G.F.; Bauerle, T.L.; Lichtenberg, E.; King, D.M.; Crawford, L. Advancing wireless sensor networks for irrigation management of ornamental crops: An overview. HortTechnology 2013, 23, 717-724. [CrossRef] 